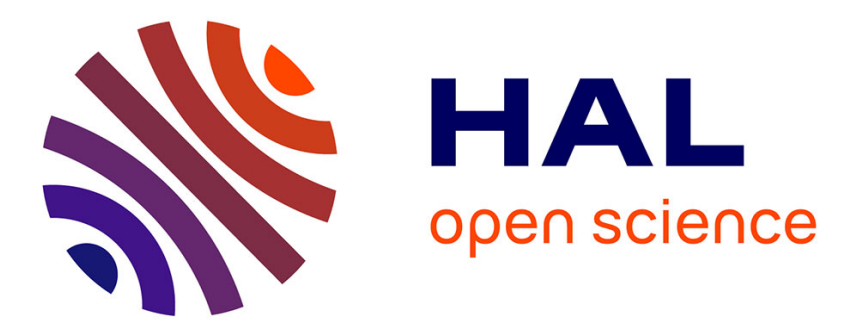

\title{
Recycling of nitrogen and light noble gases in the Central American subduction zone: constraints from 15 $\mathrm{N} 15 \mathrm{~N}$
}

Jabrane Labidi, E.D. Young, T.P. Fischer, P.H. Barry, C.J. Ballentine, J.M. de Moor

\section{To cite this version:}

Jabrane Labidi, E.D. Young, T.P. Fischer, P.H. Barry, C.J. Ballentine, et al.. Recycling of nitrogen and light noble gases in the Central American subduction zone: constraints from $15 \mathrm{~N} 15 \mathrm{~N}$. Earth and Planetary Science Letters, 2021, 571, pp.117112. 10.1016/j.epsl.2021.117112 . hal-03325181

\section{HAL Id: hal-03325181 \\ https://hal.science/hal-03325181}

Submitted on 24 Aug 2021

HAL is a multi-disciplinary open access archive for the deposit and dissemination of scientific research documents, whether they are published or not. The documents may come from teaching and research institutions in France or abroad, or from public or private research centers.
L'archive ouverte pluridisciplinaire HAL, est destinée au dépôt et à la diffusion de documents scientifiques de niveau recherche, publiés ou non, émanant des établissements d'enseignement et de recherche français ou étrangers, des laboratoires publics ou privés. 
$5 \quad{ }^{1}$ Université de Paris, Institut de physique du globe de Paris, CNRS, Paris, France

$6 \quad{ }^{2}$ Department of Earth, Planetary, and Space Sciences, UCLA, Los Angeles, CA, USA.

$7 \quad{ }^{3}$ Department of Earth and Planetary Sciences, University of New Mexico, Albuquerque, NM 87131-1116, USA

$8{ }^{4}$ Marine Chemistry and Geochemistry Department, Woods Hole Oceanographic Institution, Woods Hole MA 02543

9 USA

$10{ }^{5}$ Department of Earth Sciences, University of Oxford, OX1 3AN, UK

$11{ }^{6}$ Observatorio Volcanológico y Sismológico de Costa Rica (OVSICORI), Universidad Nacional, Costa Rica and constrain slab dehydration. However, contributions from atmospheric components in

20 fumaroles are unavoidable. For $\mathrm{N}_{2}$, neon and argon, the atmospheric components are 21 challenging to discern from slab-derived components. Here, we report ${ }^{15} \mathrm{~N}^{15} \mathrm{~N}$

22 measurements from eight fumaroles and seven bubbling springs, along the Central

23 American arc. Our new ${ }^{15} \mathrm{~N}^{15} \mathrm{~N}$ data are coupled with noble gases measurements and show 24 that air-derived components in volcanic gas discharges can easily be underestimated, in 25 both fumaroles and springs, using conventional stable isotope or noble gases methods. We 
26 show that, in the absence of ${ }^{15} \mathrm{~N}^{15} \mathrm{~N}$ data, previously used tracers for air (e.g., $\delta^{15} \mathrm{~N}, \mathrm{~N}_{2} / \mathrm{Ar}$,

$27 \mathrm{~N}_{2} / \mathrm{He}$, among others) may lead to erroneous conclusions regarding the origin of volatiles

28 in mixed gases. In contrast, ${ }^{15} \mathrm{~N}^{15} \mathrm{~N}$ data provide quantitative constraints on the nature and

29 contributions of both atmospheric and magmatic components. Most springs are heavily

30 dominated by air-derived $\mathrm{N}_{2}$, while fumaroles show substantial contributions of volcanic

31 endmembers. Based on the fumarole data, we show that magma sources beneath the

32 central American arc are enriched in all volatiles relative to ${ }^{3} \mathrm{He}$, by two to three orders of

33 magnitude compared to the MORB source. We use new ${ }^{15} \mathrm{~N}^{15} \mathrm{~N}$ data to obtain source

$34 \mathrm{~N}_{2} /{ }^{3} \mathrm{He},{ }^{3} \mathrm{He} /{ }^{36} \mathrm{Ar}$ and ${ }^{3} \mathrm{He} /{ }^{22} \mathrm{Ne}$ ratios which we then use to compute volcanic $\mathrm{N}_{2}$, $\mathrm{Ar}$ and $\mathrm{Ne}$

35 degassing fluxes. Using this approach, we show that outgassing fluxes appear to match

36 subduction fluxes in the Central America subduction zone. We determine an $\mathrm{N}_{2}$ outgassing

37 flux of between $4.0 \times 10^{8}$ and $1.0 \times 10^{9} \mathrm{~mol} \mathrm{~N} / \mathrm{y}$, comparable to the subduction flux of $5.7 \mathrm{x}$

$3810^{8} \mathrm{~mol} \mathrm{~N} / \mathrm{yr}$ determined previously. We obtain a similar conclusion for ${ }^{22} \mathrm{Ne}$ and ${ }^{36} \mathrm{Ar}$.

39 Overall, the volatile fluxes in the central American subduction zone no longer seem to 40 require net transfer of $\mathrm{N}_{2}, \mathrm{Ar}$, and $\mathrm{Ne}$, to the deep mantle.

\section{1. Introduction}

The origin of volatiles emitted from convergent margins provides fundamental

44 constraints on how plate tectonics redistributes volatiles between terrestrial reservoirs

45 (Bekaert et al., 2020; Hilton et al., 2002; Plank et al., 2013). The nitrogen cycle is under-

46 constrained, partly because quantifying degassing $\mathrm{N}_{2}$ fluxes in arcs is challenging. For

47 instance, basalt glasses are virtually absent in subduction zones, impeding quantification of

48 nitrogen elemental abundances in the underlying mantle wedge. The systematic study of 
49 metamorphic rocks has suggested nitrogen is quantitatively retained within minerals in 50 downgoing slabs (Bebout et al., 2013; Busigny et al., 2003). The latter is based on the

51 composition of rocks from the European alps, where sediments underwent metamorphism

52 in a cold subduction zone $\left(630^{\circ} \mathrm{C}\right.$ at $100 \mathrm{~km}$, Busigny et al., 2003). In those rocks, nitrogen

53 is hosted in the structures of clay minerals including micas and illites, as $\mathrm{NH}_{4}+$ substituting

54 for potassium (Bebout et al., 1992, Busigny et al., 2003; Nieder et al., 2011). Experimental

55 work confirms that the fluid/rock nitrogen partition coefficient in a cold P-T pathway is in

56 favor of $\mathrm{N}$ retention in minerals (Jackson et al., 2021). However, under warmer conditions,

57 fluid/rock partitioning favors $\mathrm{N}$ accumulation in fluids, potentially limiting nitrogen

58 subduction to the mantle (Jackson et al., 2021). Subduction temperature gradients were

59 likely steeper in most of the Proterozoic and Archean (Martin and Moyen, 2002). Therefore,

60 it is unclear how modern fluxes determined in cold subduction zones should be

61 extrapolated back into deep time.

62 The Central American Volcanic Arc (CAVA) is relatively well-characterized with

63 evidence for sedimentary and igneous components from the slab variably contributing to

64 mantle sources across the arc (Patino et al., 2000). It is a "warm" subduction zone, with

65 predicted slab interface temperatures of $\sim 800{ }^{\circ} \mathrm{C}$ at $100 \mathrm{~km}$ depth beneath Costa Rica

66 (Peacock et al., 2005), resulting in sporadic slab melting (Hoernle et al., 2008). Thus, it may

67 be considered an analog for subduction zones at a time when subduction temperature

68 gradients were steeper. In Central America, metamorphic rocks cannot be used to constrain

69 net subduction fluxes because no section of metasediments having undergone the

70 subduction P-T pathway is known to occur in the geological record. Instead, net subduction

71 fluxes of volatiles are estimated from comparing their concentrations and isotopic 
72 compositions in the offshore altered oceanic crust (Li and Bebout, 2005, Busigny et al.,

73 2019) with their concentrations and isotopic compositions in arc fumaroles that represent

74 volcanic outgassing fluxes. This mass balance calculation can be hampered by ubiquitous

75 infiltration of air into most fumaroles, as evidenced by noble gases systematics: although

76 fumaroles typically show mantle-like helium isotope ratios, neon and argon budgets are

77 overwhelmed by atmospheric components (Hilton et al., 2002; Snyder et al., 2003). This is

78 also a problem for nitrogen. Historically, $\mathrm{SO}_{2} / \mathrm{N}_{2}$ ratios from fumaroles and the overall $\mathrm{SO}_{2}$

79 outgassing flux has been used to determine a total $\mathrm{N}_{2}$ volcanic outgassing flux for the

80 central American arc, yielding a value of $1.7 \times 10^{9} \mathrm{~mol} \mathrm{~N} / \mathrm{yr}$, or $3.4 \times 10^{9} \mathrm{~mol} \mathrm{~N} / \mathrm{yr}$ (Hilton

81 et al., 2002, Fischer et al., 2002). This is comparable to an estimate of the central American

82 subduction nitrogen flux of $\sim 1.1 \times 10^{9} \mathrm{~mol} \mathrm{~N} / \mathrm{yr}$ (equivalent to $\sim 5.7 \times 10^{8} \mathrm{~mol} \mathrm{~N} / \mathrm{yr}$ ) from

83 Busigny et al. (2019). These flux estimates are given with no uncertainties, but they appear

84 comparable within a factor of 2 . Taken at face value, this would support inefficient $\mathrm{N}$ 85 recycling from the surface to the deep mantle. However, fumaroles incorporate air-derived

$86 \mathrm{~N}_{2}$, after the infiltration of meteoric water within subsurface hydrothermal systems and/or

87 because of sampling techniques (Fischer et al., 2002). Thus, the outgassing $\mathrm{N}_{2}$ fluxes based

88 on raw $\mathrm{N}_{2} / \mathrm{SO}_{2}$ ratios in fumaroles are overestimates of the outgassing $\mathrm{N}_{2}$ flux. As a remedy,

89 the volcanic fraction of $\mathrm{N}_{2}$ in fumaroles was quantified on the basis of $\mathrm{N}_{2} / \mathrm{Ar}$ ratios: air-

90 saturated waters have a known $\mathrm{N}_{2} / \mathrm{Ar}$ ratio of $\sim 40$ at STP but most hydrothermal gases in

91 the CAVA have ratios > 80 (Hilton et al., 2002; Fischer et al., 2002, Elkins et al., 2006,

92 Snyder et al., 2003; Zimmer et al., 2004). The $\mathrm{N}_{2}$ amount in excess of air-saturated water,

93 termed $\mathrm{N}_{2}{ }^{*}$, was suggested to reflect the volcanic $\mathrm{N}_{2}$ fraction (Hilton et al., 2002, Fischer et

94 al., 2002). A volcanic nitrogen degassing flux of $2.9 \times 10^{8} \mathrm{~mol} \mathrm{~N}_{2} /$ year was estimated for the 
central American arc (Fischer et al., 2002). This degassing flux estimate is lower by a factor

of 2 than the subduction nitrogen flux of $\sim 5.7 \times 10^{8} \mathrm{~mol} \mathrm{~N} /$ year (or $\sim 1.1 \times 10^{9} \mathrm{~mol} \mathrm{~N} / \mathrm{yr}$ ),

97 suggesting $\mathrm{N}_{2}$ sequestration into the deep mantle by subduction, even in a warm subduction zone (Busigny et al., 2019; Li and Bebout, 2005).

Here, we take a new approach to constrain the origin of $\mathrm{N}_{2}$ as well as light noble gases in CAVA fumaroles and springs. We use the newly-developed ${ }^{15} \mathrm{~N}^{15} \mathrm{~N}$ tracer of atmospheric

101 contamination (Labidi et al., 2020; Yeung et al., 2017; Young et al., 2016). Specifically, we 102 use $\Delta_{30}$, the ${ }^{15} \mathrm{~N}^{15} \mathrm{~N}$ concentration relative to a random distribution of ${ }^{14} \mathrm{~N}$ and ${ }^{15} \mathrm{~N}$ atoms 103 among $\mathrm{N}_{2}$ molecules, as a tracer of surficial atmospheric contamination. The $\Delta_{30}$ tracer is 104 defined as $\Delta_{30}={ }^{30} \mathrm{R} /\left({ }^{15} \mathrm{R}\right)^{2}-1(\% 0)$, where ${ }^{30} \mathrm{R}={ }^{15} \mathrm{~N}^{15} \mathrm{~N} /{ }^{14} \mathrm{~N}^{14} \mathrm{~N}$ and ${ }^{15} \mathrm{R}={ }^{15} \mathrm{~N} /{ }^{14} \mathrm{~N}$ for the gas 105 of interest. At relevant temperatures ranging from 200 to $1000{ }^{\circ} \mathrm{C}$, equilibrium among $\mathrm{N}_{2}$ 106 isotopologues results in $\Delta_{30}$ values from 0.5 to $0.1 \%$, respectively (Yeung et al., 2017). This 107 applies for any magmatic and crustal $\mathrm{N}_{2}$, whether it is mantle-derived, inherited from the 108 slab, or shallow crustal reservoirs (Labidi et al, 2020). In contrast, air has a pronounced 109 disequilibrium ${ }^{15} \mathrm{~N}^{15} \mathrm{~N}$ enrichment, leading to an atmospheric $\Delta_{30}$ value of $19.1 \pm 0.3 \%(2 \sigma)$

110 (Yeung et al., 2017). We make use of this disequilibrium as a tracer for air contributions in 111 natural fluids and identify the compositions of mantle sources for $\mathrm{N}_{2}$ and light noble gases 112 for 15 fumaroles and gases bubbling from springs in Costa Rica, Panama, Nicaragua, and El 113 Salvador. Our ${ }^{15} \mathrm{~N}^{15} \mathrm{~N}$ data allows determination of the $\mathrm{N}_{2} /{ }^{3} \mathrm{He},{ }^{3} \mathrm{He} /{ }^{36} \mathrm{Ar}$ and ${ }^{3} \mathrm{He} /{ }^{22} \mathrm{Ne}$ 114 ratios for the CAVA mantle sources. Using an updated ${ }^{3} \mathrm{He}$ outgassing flux for the region, we 115 provide a new range of estimates for the $\mathrm{N}_{2}$ outgassing flux along the Central American arc. 116 Our result has implications for the net subduction flux of nitrogen, suggesting that the net 117 sequestration of nitrogen to the mantle is within error of zero. 


\section{Geological context and samples}

The CAVA results from the eastward subduction of the Cocos Plate beneath the

121 Caribbean Plate. Abundant literature describes the spectrum of sub-arc mantle sources,

122 incorporating slab sedimentary components beneath Nicaragua, to volcanic seamounts

123 derived from Galapagos underneath Costa Rica and Panama (Carr et al., 2003; Gazel et al.,

124 2009; Hoernle et al., 2008; Patino et al., 2000; Ranero and von Huene, 2000;

125 Schwarzenbach et al., 2016).

126 Eight gas samples from fumaroles were collected from Poás and Momotombo

127 volcanoes during several field expeditions in the early to mid-2000's with gas chemistry

128 and isotope data published in Zimmer et al. (2004), Elkins et al. (2006), De Leeuw et al.,

129 (2007) and Fischer et al. (2015). Fumaroles had outlet temperatures ranging from $98^{\circ} \mathrm{C}$ to

$130747^{\circ}$ C. Samples were collected in pre-evacuated Giggenbach bottles filled with $5 \mathrm{~N} \mathrm{NaOH}$

131 solution (Giggenbach and Goguel, 1989). Gas splits were taken from the headspace of the

132 bottles with sealed glass tubes shortly after sample collection and stored until analyzed for

133 this work. Five gases from the Poás crater were collected between 2003 and 2006, from the

134 fumarolic sites "Official" and "Naranja", at temperatures between $98^{\circ} \mathrm{C}$ and $158^{\circ} \mathrm{C}$. For 135 these, we report new $\mathrm{N}_{2}$ isotopologue and ${ }^{40} \mathrm{Ar} /{ }^{36} \mathrm{Ar}$ data. ${ }^{3} \mathrm{He} /{ }^{4} \mathrm{He}$ of these samples are $1367.0 \pm 0.2 \mathrm{R}_{\mathrm{A}}$ (Hilton et al., 2010) where $\mathrm{R}_{\mathrm{A}}$ is air ${ }^{3} \mathrm{He} /{ }^{4} \mathrm{He}$ or $1.384 \times 10^{-6}$. Gas chemistry is 137 available from previous work (Fischer et al., 2015). One fumarole sample was collected at

138 Santa Ana Volcano (Salvador), with a vent temperature of $400^{\circ} \mathrm{C}$. It has a helium isotope 139 ratio of $7.5 \pm 0.1 \mathrm{R}_{\mathrm{A}}$ (De Leeuw et al., 2007). The He-Ne-Ar abundances are known (De 140 Leeuw et al., 2007). No ${ }^{40} \mathrm{Ar} /{ }^{36} \mathrm{Ar}$ is available but other gases from El Salvador all have 
141 near-atmospheric ${ }^{40} \mathrm{Ar} /{ }^{36} \mathrm{Ar}$ ratios (Snyder et al., 2003). We additionally discuss two

142 fumarole gas samples collected at Momotombo in Nicaragua, at an outlet temperature of

$143 \sim 750^{\circ} \mathrm{C}$. For these two samples, we report new ${ }^{40} \mathrm{Ar} /{ }^{36} \mathrm{Ar}$ isotope measurements. $\mathrm{N}_{2}$

144 isotopologues, helium isotopes, He-Ne-Ar and major gas chemistry data for these samples

145 are available from previous work (Elkins et al., 2006; Yeung et al., 2017). Hot springs found

146 in the flanks of volcanic arcs are the most accessible samples, and hence are routinely used

147 to characterize volcanic endmembers (e.g. Snyder et al., 2003). As a means to compare

148 these to our fumaroles, we also report data from seven gases from bubbling springs in

149 Costa Rica and Panama, collected in 2018 as part of the Biology Meets Subduction initiative.

150 Sample collection sites are shown on figure 1. Samples were collected in $15 \mathrm{~cm}^{3}$ copper

151 tubes following standard procedures. Waters in the springs had temperatures between

$15229^{\circ} \mathrm{C}$ and $55^{\circ} \mathrm{C}$. For these, we report major element gas compositions, $\mathrm{N}_{2}$ isotopologues and

153 He-Ne-Ar systematic data.

154 3. Methods

155 Gas aliquots were split up to three ways and processed for (1) gas chemistry, (2) $\mathrm{N}_{2}$, 156 and (3) noble gases systematics. Inorganic gas components (such as $\mathrm{N}_{2}, \mathrm{He}, \mathrm{Ar}$ and $\mathrm{O}_{2}$ ) and

157 methane were separated and quantified on a TCD gas chromatograph coupled with a 158 quadrupole mass spectrometer as in earlier work (Fischer et al., 2015). This allowed

159 determining the $\mathrm{N}_{2} / \mathrm{He}$ and $\mathrm{N}_{2} / \mathrm{Ar}$ ratios of each gas splits. Nitrogen isotopologues were 160 determined via high-resolution mass spectrometry at the University of California, Los 161 Angeles (Young et al., 2016). Noble gas analyses were conducted at the University of Oxford 162 (UK) and at the University of New Mexico using standard methods (Barry et al., 2016; Lee 163 et al., 2017). Details may be found in the supplementary online file. 


\section{Results}

We present an integrated dataset that includes concentrations of $\mathrm{He}, \mathrm{Ne}, \mathrm{Ar}, \mathrm{N}_{2}, \mathrm{O}_{2}$,

167 and $\mathrm{CH}_{4}$, elemental ratios of those gases, noble gas isotope compositions, and $\mathrm{N}_{2}$ 168 isotopologue ratios. Data for the fumaroles $(n=8)$ are in table 1 and data for the springs $169(\mathrm{n}=7)$ are in table 2.

\section{$172 \quad$ 4.1. $\quad \delta^{15} \mathrm{~N}$ and $\Delta 30$ relationships}

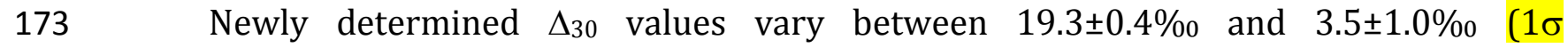
174 uncertainty, Fig. 2). Two previously published data points from Momotombo extend the 175 range down to $1.5 \pm 0.6 \%$ and are plotted on Fig. 2 (Yeung et al. 2017). The highest $\Delta_{30}$ is 176 similar to the air value of $19.1 \pm 0.3 \%(2 \sigma)$. The range in $\Delta_{30}$ values suggests samples 177 incorporate variable amounts of atmospheric nitrogen, contributing between $\sim 8$ and $178 \sim 100 \%$ of the total $\mathrm{N}_{2}$. Fumaroles from Poás and Momotombo have the lowest $\Delta_{30}$ values, 179 indicating that these fumaroles have the lowest air-derived $\mathrm{N}_{2}$ contributions. A range of $180 \delta^{15} \mathrm{~N}$ values is observed, with values of between $-3.7 \pm 0.3 \%$ and $+4.2 \pm 0.3 \%$ (Fig. 2 ). For

181 Poás and Momotombo, $\delta^{15} \mathrm{~N}$ values are $+0.4 \pm 0.3 \%$ and $+5.4 \pm 0.3 \%$ respectively, where air 182 contributions are at their lowest values (minimum $\Delta_{30}$ ). The $\delta^{15} \mathrm{~N}$ values as a whole (with 183 both low and high $\Delta_{30}$ ) are within the range of $\delta^{15} \mathrm{~N}$ values of between $-3.0 \pm 0.6$ and $1846.3 \pm 0.3 \%$ o $(n=73)$ reported previously for central American gases (Elkins et al., 2006; 185 Fischer et al., 2015, 2002; Snyder et al., 2003; Zimmer et al., 2004). The $\delta^{15} \mathrm{~N}$ values exhibit 186 a negative correlation with $\Delta_{30}$ values (Fig. 2). 


\subsection{Noble gas isotopes}

Concentrations of $\mathrm{He}, \mathrm{Ne}$ and Ar vary over 4 orders of magnitude and are correlated (Table 1 and 2). We observe ${ }^{40} \mathrm{Ar} /{ }^{36} \mathrm{Ar}$ ratios between $297 \pm 5$ and $342 \pm 5$ for our samples (Table 1 and 2), far from the upper mantle value of 25,000 (Moreira et al. 1998) but close

191 to air at 298.5 (Lee et al., 2006). This is comparable to the known range of values for 192 Central American rocks and gases of between $292 \pm 7$ and $310 \pm 5$ (Fischer et al., 2005;

193 Kennedy et al., 1991; Snyder et al., 2003; Staudacher and Allègre, 1988). The ${ }^{20} \mathrm{Ne} /{ }^{22} \mathrm{Ne}$ and $194{ }^{21} \mathrm{Ne} /{ }^{22} \mathrm{Ne}$ ratios are known only for the hot springs, and data appear indistinguishable 195 from air (Table 2).

The ${ }^{3} \mathrm{He} /{ }^{4} \mathrm{He}$ ratios vary substantially, between 0.3 and $7.6 \pm 0.1 \mathrm{R}_{\mathrm{A}}$. Unlike $\mathrm{Ne}$ and $\mathrm{Ar}$,

197 the He budget is not significantly affected by atmospheric components and instead reflect 198 appreciable deep contributions. The ${ }^{3} \mathrm{He} /{ }^{4} \mathrm{He}$ ratios are broadly correlated with ${ }^{4} \mathrm{He} /{ }^{20} \mathrm{Ne}$ 199 ratios (Fig. 3). Most of the data are explained by two-component mixing between air $200\left({ }^{3} \mathrm{He} /{ }^{4} \mathrm{He}=1 \mathrm{R}_{\mathrm{A}}\right.$ by definition, $\left.{ }^{4} \mathrm{He} /{ }^{20} \mathrm{Ne}=0.3188\right)$ and a magmatic endmember. The 201 magmatic component has a ${ }^{3} \mathrm{He} /{ }^{4} \mathrm{He}$ of $\sim 7$ (Fig. 3). The ${ }^{4} \mathrm{He} /{ }^{20} \mathrm{Ne}$ ratio of the magmatic 202 component must be at least as high as the highest value from our dataset, $\sim 270$. Three 203 Costa Rican springs show a clear offset from the two-component mixing line, showing 204 much lower ${ }^{3} \mathrm{He} /{ }^{4} \mathrm{He}$ ratios at a given ${ }^{4} \mathrm{He} /{ }^{20} \mathrm{Ne}$ value. Similar features in other Central 205 American gases were interpreted to result from mixing with gases from crustal fluids (De 206 Leeuw et al., 2007).

207 4.3. Nitrogen, oxygen and methane concentrations

208 Nitrogen concentrations vary from 0.2 vol\% to 93 vol\% in the springs, and from 0.6 209 vol\% to 1.9 vol\% in the fumaroles (Table 1 and 2). Oxygen concentrations are variable, 
210 resulting in $\mathrm{O}_{2} / \mathrm{N}_{2}$ ratios ranging over two orders of magnitude, between $3.8 \times 10^{-4}$ to $1.1 \mathrm{x}$

$21110^{-1}$ (Supplementary Fig. 1). The $\mathrm{O}_{2} / \mathrm{N}_{2}$ ratios are not directly correlated with $\Delta_{30}$ values

212 (supplementary Fig. 1), suggesting that $\mathrm{O}_{2} / \mathrm{N}_{2}$ is not a reliable indicator of the presence of

213 nitrogen from air. Methane concentrations are below $0.1 \mathrm{vol} \%$ for most samples, with the

214 exception of two of the Costa Rica hot springs, where $\mathrm{CH}_{4}$ concentrations are as high as $\sim 80$

215 vol \%, suggesting contributions from shallow crustal gases (Snyder et al. 2003). $\mathrm{N}_{2} / \mathrm{CH}_{4}$

216 varies over 5 orders of magnitude, between $\sim 1.2 \times 10^{-1}$ to $\sim 2.1 \times 10^{4}$, but remains

217 uncorrelated with $\Delta_{30}$ values (Supplementary Fig. 1).

218 4.4. Nitrogen - noble gas ratios

219 We compute $\mathrm{N}_{2} / \mathrm{Ar}, \mathrm{N}_{2} /{ }^{36} \mathrm{Ar}, \mathrm{N}_{2} / \mathrm{He}$ and $\mathrm{N}_{2} /{ }^{3} \mathrm{He}$ ratios, with a $\pm 20 \%$ relative 220 uncertainty on individual samples. $\mathrm{N}_{2}$ /Ar ratios are between 21 and 120 for most samples,

221 with one sample from Momotombo at 507 (Fig. 4). For comparison, the air value is $\sim 84$,

222 air-saturated water (ASW) at STP is $\sim 41$, and MORB gases have $\mathrm{N}_{2} / \mathrm{Ar}$ ratios of $55 \pm 5$ (Javoy

223 and Pineau, 1991), although a higher estimate of $\sim 120 \pm 40$ (Marty and Dauphas, 2003) was

224 derived from MORB samples with unusually radiogenic ${ }^{40} \mathrm{Ar} /{ }^{36} \mathrm{Ar}$ ratios (data from Marty 225 et al., 1999). For samples where ${ }^{40} \mathrm{Ar} /{ }^{36} \mathrm{Ar}$ was measured, $\mathrm{N}_{2} /{ }^{36} \mathrm{Ar}$ ratios vary between $2261.2 \times 10^{4}$ and $4.2 \times 10^{4}$. Assuming the ${ }^{40} \mathrm{Ar} /{ }^{36} \mathrm{Ar}$ is atmospheric as for other Central 227 American gas samples (Snyder et al., 2003), the $\mathrm{N}_{2} /{ }^{36} \mathrm{Ar}$ range extends to between $2286.5 \times 10^{3}$ and $1.5 \times 10^{5}$ (Fig. 4). This includes values below and above both air $\left(2.5 \times 10^{4}\right)$ 229 and air-saturated water at STP $\left(1.3 \times 10^{4}\right)$. The highest $\mathrm{N}_{2} /{ }^{36} \mathrm{Ar}$ value remains well below 230 estimates of the convective mantle of $\sim 2 \times 10^{6}$ (Labidi et al., 2020; Marty and Humbert, 231 1997) even for samples where $\Delta_{30}$ is low. 
The $\mathrm{N}_{2}$ /He ratios vary between $1.5 \times 10^{2}$ and $4.2 \times 10^{4}$, below the value of air of

$2331.5 \times 10^{5}$ or air-saturated water $\sim 3.0 \times 10^{5}$ (Fig. 5). Similarly, $\mathrm{N}_{2} /{ }^{3} \mathrm{He}$ ratios vary between

$2341.6 \times 10^{7}$ and $1.1 \times 10^{11}$ (Fig. 5), mostly below the value of air and ASW of $1.0 \times 10^{11}$ and $235 \sim 2.0 \times 10^{11}$ respectively (Ballentine et al., 2002). The $\mathrm{N}_{2} / \mathrm{He}$ (and $\mathrm{N}_{2} /{ }^{3} \mathrm{He}$ ratios) are

236 correlated with $\Delta_{30}$ values and are described by two-component mixing hyperbolae

237 between air (or air-saturated waters) and high-temperature components with elevated

$238 \mathrm{~N}_{2} / \mathrm{He}$ (and $\mathrm{N}_{2} /{ }^{3} \mathrm{He}$ ratios) relative to MORB gases (Fig. 5).

\section{4.5. Noble gas ratios}

240 The ${ }^{3} \mathrm{He} /{ }^{22} \mathrm{Ne}$ ratios range over 4 orders of magnitude, between $8.9 \times 10^{-6}$ and

$2412.7 \times 10^{-2}$ (Fig. 6). These values are between air, at $4.5 \times 10^{-6}$, and upper-mantle gases at

$242 \sim 5.5 \times 10^{1}$ (Moreira et al., 1998). The ${ }^{4} \mathrm{He} /{ }^{20} \mathrm{Ne}$ ratios are also ranging between air and the

243 upper-mantle value (Supplementary Figure 2). ${ }^{3} \mathrm{He} /{ }^{22} \mathrm{Ne}$ (and ${ }^{4} \mathrm{He} /{ }^{20} \mathrm{Ne}$ ) ratios are

244 correlated with $\Delta_{30}$ values (Fig. 6, Supp Fig. 2). At $\Delta_{30}=0$ the high-temperature component

245 appears to have He/Ne ratios lower than MORB gases by about four orders of magnitude

246 (Fig. 6, Supp Fig. 2). The ${ }^{3} \mathrm{He} /{ }^{36} \mathrm{Ar}$ ratio ranges between $1.6 \times 10^{-6}$ and $1.7 \times 10^{-4}$ (Fig. 6).

247 This is higher than the air value of $2.5 \times 10^{-7}$, but considerably lower than the upper-

248 mantle value of $\sim 5.0 \times 10^{-1}$ (Moreira et al., 1998; Raquin et al., 2008). A similar

249 observation can be made of the ${ }^{4} \mathrm{He} /{ }^{40} \mathrm{Ar}$ ratio (Supp Fig. 2). The variations in ${ }^{3} \mathrm{He} /{ }^{36} \mathrm{Ar}$

250 (and ${ }^{4} \mathrm{He} /{ }^{40} \mathrm{Ar}$ ) ratios are correlated with $\Delta_{30}$ values and at $\Delta_{30}=0$, the high-T component

251 shows ${ }^{3} \mathrm{He} /{ }^{36} \mathrm{Ar}$ ratios lower than MORB gases by about three orders of magnitude (Fig. 6,

252 Supp Fig. 2). Most ${ }^{22} \mathrm{Ne} /{ }^{36} \mathrm{Ar}$ ratios in fumaroles and springs range between $1.3 \times 10^{-1}$ and

$2533.1 \times 10^{-3}$ (with one outlier at $\sim 6.5 \times 10^{-1}$, the Poás gas with the $\Delta_{30}$ value closest to air).

254 The higher values are similar to the air and MORB values of $5.0 \times 10^{-2}$ and $1.0 \times 10^{-1}$, 
255 respectively (Mukhopadhyay, 2012) and are observed for samples with air-like $\Delta_{30}$ values.

256 At $\Delta_{30}=0$, much lower ${ }^{22} \mathrm{Ne} /{ }^{36} \mathrm{Ar}$ values are observed, lower than both MORB and air by

257 one to two orders of magnitude (Table 1 and 2).

258

259 5. Discussion

260 Our rationale is that correlations between $\Delta_{30}$ and various isotope and element ratios

261 can be used to identify and correct for air components and reveal pristine high-

262 temperature endmembers. Air is identified with a $\Delta_{30}$ of $19.1 \pm 0.3 \%$, while any $\mathrm{N}_{2}$

263 produced by a geologic process such as magmatic degassing has $\Delta_{30} \sim 0 \%$ (Labidi et al.,

264 2020). Arguments against re-ordering and crustal contamination are given in the

265 supplementary discussion.

266

2675.1 Atmospheric $\mathrm{N}_{2}$ may easily go unnoticed

268 CAVA gas $\Delta_{30}$ values are variable, indicating commensurately variable contributions of 269 air to the $\mathrm{N}_{2}$ budgets in hydrothermal discharges. Based on $\Delta_{30}$ data, air accounts for 40 to

$270100 \%$ of the $\mathrm{N}_{2}$ in the springs. In fumaroles, air accounts for 8 to $90 \%$ of the $\mathrm{N}_{2}$.

271 Atmospheric $\mathrm{N}_{2}$ is therefore ubiquitous. Systematics involving $\delta^{15} \mathrm{~N},\left[\mathrm{O}_{2}\right], \mathrm{O}_{2} / \mathrm{N}_{2}, \mathrm{~N}_{2} / \mathrm{He}$ and

$272 \mathrm{~N}_{2} /$ Ar ratios may disentangle magmatic $\mathrm{N}_{2}$ from air-derived $\mathrm{N}_{2}$ in gas discharges (Sano et

273 al., 2001, Fischer et al. 2002, Elkins et al., 2006). The rationale for all of those approaches is

274 that air has known $\delta^{15} \mathrm{~N}, \mathrm{O}_{2} / \mathrm{N}_{2}, \mathrm{~N}_{2} / \mathrm{He}$ and $\mathrm{N}_{2} /$ Ar ratios, that are different from magmatic

275 components. Our $\Delta_{30}$ data present a series of challenges to these previous approaches. For

276 example, samples with high ${ }^{4} \mathrm{He} /{ }^{20} \mathrm{Ne}$ ratios were suggested to illustrate a volatile budget

277 largely uncontaminated by air, especially when a number of other criteria are met, e.g., 
$278 \mathrm{O}_{2} / \mathrm{N}_{2}$ ratios $<10^{-3}$, high outlet temperatures, or non-atmospheric $\mathrm{N}_{2} / \mathrm{Ar}$ ratios (Elkins et

279 al., 2006). The Santa Ana volcano fumarole is vented at $400^{\circ} \mathrm{C}$, a ${ }^{4} \mathrm{He} /{ }^{20} \mathrm{Ne} \sim 200$ times

280 higher than air and a $\mathrm{O}_{2} / \mathrm{N}_{2}$ ratio of $\sim 10^{-4}$ (Table 1, Fig. 3), which would suggest minimal air

281 contamination. However, the near-air $\Delta_{30}$ of $15.5 \pm 0.3 \%$ requires that $\sim 80 \%$ of $\mathrm{N}_{2}$ is from

282 air in this sample, showing that high ${ }^{4} \mathrm{He} /{ }^{20} \mathrm{Ne}$, even in conjunction with high vent

283 temperature and low $\mathrm{O}_{2} / \mathrm{N}_{2}$, is not necessarily sufficient evidence that $\mathrm{N}_{2}$ is dominantly

284 magmatic (See supplementary discussion).

285

286

2875.2 Atmospheric $\mathbf{N}_{2}$ undergoes isotopic fractionation in hydrothermal systems

288 Nitrogen isotope ratios could be a direct tracer of atmospheric $\mathrm{N}_{2}$, since air and 289 magma-derived nitrogen are thought to have distinct $\delta^{15} \mathrm{~N}$ values (Fischer et al., 2002, Sano

290 et al., 2001). The $\Delta_{30}$ data confirm the veracity of this approach for most, but not all,

291 samples. Gases (except those from Poás) fall on a single two-component mixing trend

292 between air and a high-temperature component with near-zero $\Delta_{30}$ and $\delta^{15} \mathrm{~N}$ of $\sim 5 \%$ (Fig.

293 2). For those, the air component appears unfractionated with respect to $\delta^{15} \mathrm{~N}$. When mixed

294 with high-temperature volatiles, $\delta^{15} \mathrm{~N}$ increases and $\Delta_{30}$ values decrease (Fig. 2).

295 Samples from Poás are different. They form a unique linear mixing trend where both 296 air-derived and high-temperature $\mathrm{N}_{2}$ are distinct from elsewhere in the arc system, with $297 \delta \delta^{15} \mathrm{~N}$ endmember values of $-4.0 \pm 0.3 \%$ and $+1.0 \pm 0.3 \%$ for air and the high-T component, 298 respectively (Fig. 2). This represents a $\sim 4 \%$ o shift for both endmembers compared to 299 values observed elsewhere on the arc. Our observation creates ambiguities at Poás, since 300 there, and there only: (1) high-temperature $\delta^{15} \mathrm{~N}$ is only marginally higher than air; and (2) 
301 air-derived $N_{2}$ has a $\delta^{15} \mathrm{~N}$ very similar to the MORB value of $-5 \pm 2 \%$ (Javoy and Pineau, 302 1991, Marty et al., 1999).

303 The data from Poás require that atmospheric $\mathrm{N}_{2}$ experienced a $\sim 4 \%$ mass-dependent $304{ }^{15} \mathrm{~N} /{ }^{14} \mathrm{~N}$ fractionation in the sub-surface. This may result from the degassing of once air305 saturated waters. The isotopic fractionation associated with $\mathrm{N}_{2}$ dissolved in water was 306 experimentally documented to be +0.9 to $-0.4 \%$ from 6 to $60{ }^{\circ} \mathrm{C}$ (Lee et al., 2015). The 307 dissolved-gas isotope fractionation was shown to cross over at about $40{ }^{\circ} \mathrm{C}$, from a positive 308 to a negative sign (Lee et al., 2015). Above $40^{\circ} \mathrm{C}$, the isotopic difference between dissolved 309 and gaseous $\mathrm{N}_{2}$ increases: isotopically light $\mathrm{N}_{2}$ is increasingly partitioned in the dissolved 310 fraction as temperature increases. This behavior indicates that a kinetic isotope effect 311 attends $\mathrm{N}_{2}$ dissolution/degassing in geothermal waters (Lee et al., 2015). Using the 312 experimental results of Lee et al., (2015), we calculate the consequences of $\mathrm{N}$ isotope 313 fractionation during open-system degassing using Rayleigh fractionation. At $60{ }^{\circ} \mathrm{C}$, with a 314 gas/dissolved-gas ${ }^{15} \mathrm{~N} /{ }^{14} \mathrm{~N}$ fractionation factor of 1.0004 , the lowest $\delta^{15} \mathrm{~N}$ values of $\sim-3.5$ $315 \%$ with air-like $\Delta_{30}$ require that the $\mathrm{N}_{2}$ sampled by the fumaroles is the residuum left over 316 after degassing of about $99.98 \%$ of the dissolved nitrogen. Extrapolating the temperature 317 dependence of the fractionation factor to $100{ }^{\circ} \mathrm{C}, 97 \%$ degassing of $\mathrm{N}_{2}$ is required to 318 account for a $\delta^{15} \mathrm{~N}$ of $\sim-3.5 \%$.

319 We envision the hydrothermal degassing to be the natural consequence of 320 hydrothermal systems experiencing continuous degassing in the absence of continuous 321 meteoric (air-saturated) water recharge. It is puzzling however that among the sites we 322 sampled, air nitrogen undergoes isotopic fractionation only at Poás. In order to explain this 323 observation, we suggest a restricted set of conditions is met in the Poás subsurface, but not 
324 elsewhere. Gases from Momotombo and Santa Ana are vented at temperatures between $325747{ }^{\circ} \mathrm{C}$ and $400{ }^{\circ} \mathrm{C}$, respectively. No liquid water remains stable at those temperatures.

326 Thus, isotope partitioning between water and gas is not occurring, and $\mathrm{N}_{2}$ remains

327 unfractionated. Spring gases are vented at temperatures between $29^{\circ} \mathrm{C}$ and $59{ }^{\circ} \mathrm{C}$ (Table 2),

328 at temperatures where degassing is probably limited. In contrast, at Poás, the fumaroles are

329 vented at $\sim 100-150{ }^{\circ} \mathrm{C}$ (Fischer et al., 2015). At these temperatures, liquid and gaseous

330 water are stable and water/gas partitioning can occur. These conditions are comparable to

331 those observed for hydrothermal gases from Iceland or Yellowstone, where negative $\delta^{15} \mathrm{~N}$

332 values were previously observed in conjunction with air like $\Delta_{30}$ values (Labidi et al., 2020).

333 Our conclusion is also consistent with the observation of sporadically negative $\delta^{15} \mathrm{~N}$ (with

334 no available $\Delta_{30}$ data) in Poás fumaroles sampled in 2001. Values as low as $\sim-3.0 \%$ were

335 observed in fumarole vented at temperature between 76 and $108{ }^{\circ} \mathrm{C}$ (Fischer et al., 2002).

336 In other fumaroles $\left(89-101^{\circ} \mathrm{C}\right)$ sampled between 1998 and 2001, while unfractionated air-

337 like $\delta^{15} \mathrm{~N}$ and $\mathrm{N}_{2} / \mathrm{Ar}$ values were reported (Vaselli et al., 2003). More work is warranted to

338 follow the potential $\Delta_{30-} \delta^{15} \mathrm{~N}$ evolution of a given fumarole through time, but in the interim,

339 we suggest caution in interpreting $\delta^{15} \mathrm{~N}$ data at Poás in the absence of $\Delta_{30}$.

$341 \quad 5.3 . \quad$ Is high-temperature nitrogen also fractionated?

342 Whether high-temperature components with $\Delta_{30} \sim 0 \%$ also experience $\delta^{15} \mathrm{~N}$ isotope

343 fractionation in hydrothermal systems is an open question. At Momotombo, fumaroles have

344 a high-temperature endmember with $\delta^{15} \mathrm{~N} \sim+5 \%$ (Fig. 2.). There, vent temperatures are >

$345700{ }^{\circ} \mathrm{C}$. This precludes liquid water to exist even at depths, ruling out the possibility of any

346 water/gas isotope exchange. This is consistent with a previous observation of 
347 unfractionated $\delta^{15} \mathrm{~N}$ for fumaroles when they are vented at $>300{ }^{\circ} \mathrm{C}$ (Fischer et al., 2005).

348 At Poás however, the interpretation is not as straightforward, where the high-temperature

349 endmember has a $\delta^{15} \mathrm{~N} \sim+1 \%$ o (Fig. 2), which is lower than at Momotombo by $\sim 4 \%$,

350 implying that a fractionation similar to that for the air component could have occurred. It

351 is conceivable that high-T volatiles have been delivered to the water table prior to

352 hydrothermal degassing, where they would experience ${ }^{15} \mathrm{~N} /{ }^{14} \mathrm{~N}$ fractionation together with

353 the air-derived gases. In this interpretation, the high-T $\delta^{15} \mathrm{~N}$ value of $\sim+1 \%$ obtained by

354 extrapolation to $\Delta_{30}=0$ would not record the actual magmatic $\delta^{15} \mathrm{~N}$ value at Poás, and the

355 Poás trend would be parallel to the main array as the result of a fractionation equally

356 affecting both the atmospheric and high-T volatiles. However, with our dataset alone, we

357 cannot exclude that high- $\mathrm{T}$ volatiles had been delivered to the fumaroles after 358 hydrothermal degassing. If so, the Poás high-T endmember could be truly unique in $\delta^{15} \mathrm{~N}$, 359 and the Poás trend being parallel to the main array (Fig. 2) would be fortuitous. This latter 360 scenario relies on a coincidence, and thus appears unlikely, although it cannot be fully ruled 361 out.

362

363 5.4. $\mathrm{N}_{2}$ /Ar ratios place independent constraints on hydrothermal degassing

364 The solubilities of argon and nitrogen are distinct by about a factor of 2 in geothermal 365 waters at temperatures between 20 and $100{ }^{\circ} \mathrm{C}$ (Ballentine et al, 2002). Thus, water/gas 366 processes may be tracked with $\mathrm{N}_{2} / \mathrm{Ar}$ ratios, independently of nitrogen isotopes. Low $367 \mathrm{~N}_{2} / \mathrm{Ar}$ ratios for air-like $\Delta_{30}$ values are observed at Poás, while most other samples have 368 near-air values for $\mathrm{N}_{2} / \mathrm{Ar}$ at air-like $\Delta_{30}$ (Fig. 4), confirming that at Poás liquid-gas 
369 partitioning occurred in the sub-surface. We can again use a Rayleigh fractionation

370 calculation to infer the amount of degassing implied by the $\mathrm{N}_{2} / \mathrm{Ar}$ ratio data, where

$$
\mathrm{N}_{2} / \mathrm{Ar}=\left(\mathrm{N}_{2} / \mathrm{Ar}\right)_{0} f^{\alpha_{-1}}
$$

372 and

$$
\alpha=\left(\mathrm{K}_{\mathrm{N}_{2}} / \mathrm{K}_{\mathrm{Ar}}\right),
$$

374 where $f$ is the fraction of remaining $\mathrm{Ar}$ in the water, $\left(\mathrm{N}_{2} / \mathrm{Ar}\right)_{0}$ the known starting 375 composition of ASW, and $\alpha$ is the fractionation coefficient given for a gas/liquid system 376 given by Equation (2), and $K_{i}$ is the Henry's-law constant for species $i$, as compiled in 377 Ballentine et al., (2002). Taking $\left(\mathrm{N}_{2} / \mathrm{Ar}\right)_{0}$ to be 41 , we find that the lowest $\mathrm{N}_{2} / \mathrm{Ar}$ value of $\sim$ 37810 implied by our data occurs for about $94 \%$ degassing of $\mathrm{N}_{2}$ ( $75 \%$ degassing of $\mathrm{Ar}$ ) prior 379 to sampling (Fig. 4). To first order, this degree of degassing is consistent with estimates 380 made on the basis of ${ }^{15} \mathrm{~N} /{ }^{14} \mathrm{~N}$ values (section 5.2 ).

381 There is a caveat to this interpretation. Data for $\delta^{15} \mathrm{~N}$ and $\mathrm{N}_{2} / \mathrm{Ar}$ appear consistent 382 with fractionation within hydrothermal systems, but no direct correlation is observed 383 between $\delta^{15} \mathrm{~N}$ and $\mathrm{N}_{2} / \mathrm{Ar}$ (Table 1 ). This is perhaps because degassing may yield variable $384{ }^{15} \mathrm{~N} /{ }^{14} \mathrm{~N}$ and $\mathrm{N}_{2} / \mathrm{Ar}$ fractionations depending on the exact temperature and pressure 385 conditions (Lee et al., 2015; Warr et al., 2015). Under conditions making the gas behavior 386 non-ideal, degassing may change the $\mathrm{N}_{2}$-Ar solubility relationship, as suggested for heavier 387 noble gases (Labidi et al., 2020, Warr et al., 2015). Additionally, small contributions of high388 temperature volatiles are likely to cause shifts in $\delta^{15} \mathrm{~N}$ with no obvious increases in $\mathrm{N}_{2} / \mathrm{Ar}$ 389 ratios (Fig. 4). This is because high-temperature endmembers with $\Delta_{30}=0 \%$ appear to 390 have $\mathrm{N}_{2} / \mathrm{Ar}$ and $\mathrm{N}_{2} /{ }^{36} \mathrm{Ar}$ ratios of $\sim 100$ and $\sim 10^{4}$, respectively (Fig. 4). These values are 
391 essentially similar to air, consistent with pioneer work on the CAVA (Hilton et al., 2002;

392 Snyder et al., 2003), but remain lower than volcanic endmembers at other arcs (Taran,

393 2009; Zelenski and Taran, 2011). We note that one of the Momotombo fumaroles has a high

$394 \mathrm{~N}_{2} /$ Ar of $\sim 500$, higher than other high-temperature gases by a factor of 5 . The significance

395 of variable $\mathrm{N}_{2} / \mathrm{Ar}$ ratios in Central American high-temperature endmembers must be 396 systematically investigated in future work, with $\Delta_{30}$ data.

\section{5. $\delta^{15} \mathrm{~N}-\mathrm{N}_{2} / \mathrm{He}$ relationships constrained by $\Delta_{30}$ data}

In contrast to argon, the solubility of helium in geothermal waters is nearly

400 indistinguishable from that of nitrogen in the relevant temperature range (Ballentine et al., 401 2002). Data can be accounted for by mixing between air and an endmember with $\mathrm{N}_{2} /{ }^{3} \mathrm{He}$ 402 ratios $\sim 10^{8}$ (Fig. 5). This is higher than MORB gases that are characterized by $\mathrm{N}_{2} /{ }^{3} \mathrm{He}$ 403 ratios of about $10^{6}$ (Javoy and Pineau, 1991, Marty and Humbert, 1999). The Poás 404 fumaroles involve a mixing scenario that is similar to the one for Momotombo, involving 405 high-T endmembers with a $\mathrm{N}_{2} /{ }^{3} \mathrm{He}$ of $\sim 10^{8}$ (Fig. 5). This observation argues against a 406 significant contribution of MORB derived volatiles to Poás volcanic gas discharges. Overall 407 light $\delta^{15} \mathrm{~N}$ values from Poás were previously suggested to reflect a contribution from 408 MORB-derived volatiles, contrary to the majority of other CAVA gas discharges that showed 409 predominantly slab-derived N (Fischer et al., 2002, Elkins et al., 2006). Our new $\Delta_{30}$ data 410 suggest a revision to the interpretation of ${ }^{15} \mathrm{~N}$ depletions and show that they rather reflect 411 contributions of fractionated air (Fig. 2) mixed with a predominantly non-MORB magmatic 412 component with elevated $\mathrm{N}_{2} /$ He ratios (Fig. 5). 


\section{5.6. Magmatic endmembers throughout the arc are enriched in $\mathrm{N}_{2}$}

415 In an attempt to characterize subduction volatiles, we constrain the high-temperature 416 endmembers for nitrogen isotopes and $\mathrm{N}_{2} / \mathrm{Ar}, \mathrm{N}_{2} / \mathrm{He}, \mathrm{He} / \mathrm{Ne}$ and $\mathrm{He} / \mathrm{Ar}$ ratios. 417 Endmember compositions are calculated assuming two-component mixing with air 418 constrained by $\Delta_{30}$ values, as described above. We focus on fumarole data to constrain 419 endmember compositions, since they show the lowest $\Delta_{30}$ and no evidence of crustal 420 contamination (see supplementary discussion).

421 The derived $\mathrm{N}_{2}$ /He ratios are higher than MORB by two orders of magnitude. In 422 contrast, $\mathrm{He} / \mathrm{Ne}, \mathrm{He} / \mathrm{Ar}$ and $\mathrm{N}_{2} /{ }^{36} \mathrm{Ar}$ are all lower than MORB by two to three orders of 423 magnitude (Fig. 4-6). The simplest explanation is that slab-derived $\mathrm{N}_{2}$, $\mathrm{Ne}$ and $\mathrm{Ar}$ were 424 added to a depleted mantle source with an unmodified helium signature (Fig. 7). A 425 straightforward quantification of slab-derived $\mathrm{N}_{2}, \mathrm{Ar}$ and $\mathrm{Ne}$ to the mantle wedge is 426 possible using $\mathrm{N}_{2} /{ }^{3} \mathrm{He},{ }^{3} \mathrm{He} /{ }^{22} \mathrm{Ne}$ and ${ }^{3} \mathrm{He} /{ }^{36} \mathrm{Ar}$ ratios. This approach is viable if ${ }^{3} \mathrm{He}$

427 subduction is negligible (Staudacher and Allegre, 1988), notwithstanding that slab 428 components are required to contribute minute ${ }^{4} \mathrm{He}$ ingrowth from subducted uranium 429 (Hilton et al., 2002).

430 The high-T, arc magma endmembers at Poás and Momotombo have $\mathrm{N}_{2} /{ }^{3}$ He ratios two 431 orders of magnitude higher than MORB, requiring nitrogen addition to mantle sources in 432 these arc systems. Sedimentary nitrogen may be a straightforward contributor to the 433 Momotombo source, explaining the high $\delta^{15} \mathrm{~N}$ of $+5 \%$ there (Fig. 7). Sediments on the 434 modern oceanic crust directly offshore of Central America are likely candidates, since they 435 have an average $\delta^{15} \mathrm{~N}$ of $\sim 5 \%$ ( $\mathrm{Li}$ and Bebout, 2005). Poás volcano is more complicated, 436 because the lower $\delta^{15} \mathrm{~N}$ (Fig. 2) may not be a genuine representation of the Poás mantle 
437 source. We note that because $\mathrm{N}_{2} /{ }^{3} \mathrm{He}$ are indistinguishable between Poás and Momotombo, 438 they must have received a comparable amount of slab-derived $\mathrm{N}$.

439 Sub-arc magmatic endmembers have lower ${ }^{3} \mathrm{He} /{ }^{22} \mathrm{Ne}$ and ${ }^{3} \mathrm{He} /{ }^{36} \mathrm{Ar}$ ratios by 2 to 3 440 orders of magnitude compared to those of MORBs. Like nitrogen, this likely requires 441 substantial addition of slab-derived neon and argon to a mantle source. Samples with near442 zero $\Delta_{30}$ have ${ }^{22} \mathrm{Ne} /{ }^{36} \mathrm{Ar}$ lower than both MORB and air by one to two orders of magnitude 443 (Table 1), with values trending toward $\sim 0.7 \times 10^{-2}$. This is similar to the median ratio of 444 an entire section of altered oceanic crust and sediments of $\sim 1 \times 10^{-2}$ (Chavrit et al., 2016). 445 The similarity in ${ }^{22} \mathrm{Ne} /{ }^{36} \mathrm{Ar}$ between the magmatic endmembers at CAVA and the slab is 446 consistent with a mantle wedge being overwhelmed by the addition of slab-derived neon 447 and argon. Samples with near-zero $\Delta_{30}$ also have atmospheric ${ }^{40} \mathrm{Ar} /{ }^{36} \mathrm{Ar}$ values (Table 1 ), 448 indicating that Ar from the mantle wedge has retained the noble gas isotopic signature of 449 its subducted atmospheric source. This is likely explained by the contribution of surface450 derived argon with atmospheric ${ }^{40} \mathrm{Ar} /{ }^{36} \mathrm{Ar}$ ratios to the mantle wedge. This sheds new light 451 on atmospheric ${ }^{40} \mathrm{Ar} /{ }^{36} \mathrm{Ar}$ observed systematically in all known Central American 452 fumaroles (Snyder et al. 2003) and essentially all gas discharges sampled to date from 453 subduction zones (Hilton et al., 2002, Sano and Fischer, 2013): A likely origin for the 454 atmospheric Ar in high-T endmembers is devolatilizing subducted protoliths that are 455 otherwise known to have atmospheric Ar isotopic signatures (Chavrit et al., 2016; Holland 456 and Ballentine, 2006; Staudacher and Allègre, 1988). Our high-T data shows that not all of 457 the subducted air-derived Ar is transferred into the deeper mantle and that some of it is 458 released via arc volcanism. Our data also dispels the notion that atmospheric Ar-isotope 
459 signatures of arc-gases are exclusively the result of shallow atmospheric contamination in 460 the hydrothermal system.

\subsection{Revisiting volatile fluxes in the central American subduction zone.}

The perspective that volatiles from the mantle wedge incorporate recycled argon is 464 problematic, as it limits the use of nitrogen excesses, $\mathrm{N}_{2}{ }^{*}$, calculated on the basis of $\mathrm{N}_{2} / \mathrm{Ar}$ 465 ratios (Fischer et al. 1998,2002, Hilton et al., 2002). We show here that magmatic volatiles 466 deliver measurable amounts of argon (with atmospheric ${ }^{40} \mathrm{Ar} /{ }^{36} \mathrm{Ar}$ ) to the fumaroles. 467 Consequently, assumptions on $\mathrm{N}_{2}{ }^{*}$ may naturally underestimates the outgassing flux of $\mathrm{N}_{2}$. 468 Estimates for the fluxes of $\mathrm{N}_{2}, \mathrm{Ar}$, and $\mathrm{Ne}$ can be obtained from ${ }^{3} \mathrm{He}$ degassing fluxes. Using a 469 combination of $\mathrm{S} / \mathrm{CO}_{2}, \mathrm{He} / \mathrm{CO}_{2}$ and ${ }^{3} \mathrm{He} /{ }^{4} \mathrm{He}$ ratios, and an $\mathrm{SO}_{2}$ flux of $21.3 \times 10^{9} \mathrm{~mol} / \mathrm{yr}$, 470 Hilton et al. (2002) derived a ${ }^{3} \mathrm{He}$ flux of $5.4 \mathrm{~mol} / \mathrm{yr}$ for the entire CAVA. Using the CAVA $471 \mathrm{CO}_{2}$ flux from Fischer et al., (2019) of $94 \times 10^{9} \mathrm{~mol} / \mathrm{yr}$, and a $\mathrm{CO}_{2} /{ }^{3} \mathrm{He}$ ratio of $2 \times 10^{10}$ 472 (Kagoshima et al., 2015), we obtain a ${ }^{3} \mathrm{He}$ flux $4.7 \mathrm{~mol} / \mathrm{yr}$. Here, we take a ${ }^{3} \mathrm{He}$ flux of 5.0

$473 \mathrm{~mol} / \mathrm{yr}$ for the sake of illustration. We combine our new elemental ratios estimates for the 474 CAVA source (Fig. 4-6) with ${ }^{3} \mathrm{He}$ fluxes to derive new estimates for $\mathrm{N}_{2},{ }^{36} \mathrm{Ar}$, and ${ }^{22} \mathrm{Ne}$ 475 outgassing fluxes in the central American arc.

476 We derive $\mathrm{N}_{2} /{ }^{3} \mathrm{He}$ ratios between $8 \times 10^{7}$ and $2 \times 10^{8}$ for magmatic volatiles in Central

477 America (Fig. 5), from samples with $\Delta_{30}<5 \%$. This results in a $\mathrm{N}_{2}$ flux between $4.0 \times 10^{8}$ 478 and $1.0 \times 10^{9} \mathrm{~mol} \mathrm{~N}_{2} / \mathrm{y}$ ( or $1.1 \times 10^{10}$ and $2.8 \times 10^{10} \mathrm{~g} \mathrm{~N} / \mathrm{y}$ ). This range for the nitrogen mass

479 flux is higher than previous estimates of $8.2 \times 10^{9} \mathrm{~g} \mathrm{~N} / \mathrm{y}$ (Fischer et al., 2002, Hilton et al., 480 2002). Our derived range of nitrogen fluxes overlaps the estimated flux of subducting 481 nitrogen of $1.6 \times 10^{10} \mathrm{~g} \mathrm{~N} / \mathrm{y}\left(1.1 \times 10^{9} \mathrm{~mol} \mathrm{~N} / \mathrm{y}\right.$, or $\left.5.7 \times 10^{8} \mathrm{~mol} \mathrm{~N} / \mathrm{yr}\right)$, given with no 
482 uncertainty in Busigny et al. (2019) and Li and Bebout (2005). This suggests that in the

483 Central American subduction zone, the $\mathrm{N}_{2}$ cycle is not required to be out of equilibrium.

484 Instead, the revisited fluxes being identical within uncertainty, they allow $\mathrm{N}_{2}$ to be 485 quantitatively recycled through the mantle wedge and returned to the surface by degassing 486 rather than being delivered to the deep mantle. An additional source of outgassing 487 underestimation, here, is that we ignore forearc devolatilization for $\mathrm{N}_{2}$, known to occur in 488 the CAVA (Inguaggiato et al., 2004). Future work will be necessary to constrain this fraction 489 of the $\mathrm{N}_{2}$ flux that will inevitably increase the outgassing flux further. In any case, our newly 490 defined $\mathrm{N}_{2}$ outgassing fluxes are high, and in the range of subducting fluxes. Because this 491 subduction zone is relatively "warm" and therefore more similar to subduction zones in the 492 past over geological timescales (Keller and Schoene, 2018; Martin and Moyen, 2002), the 493 finding that nitrogen is recycled by subduction and arc magmatism in the Central American 494 system suggests that nitrogen subduction could have been inefficient through geological 495 time. This conclusion is also in agreement with recent experimental work suggesting warm 496 subduction zones limit nitrogen recycling in the deep mantle (Jackson et al., 2021).

497 We estimate the ${ }^{3} \mathrm{He} /{ }^{36} \mathrm{Ar}$ of magmatic inputs to be $\sim 10^{-4}$ (Fig. 6). A ${ }^{3} \mathrm{He} /{ }^{36} \mathrm{Ar}$ ratio of $498 \sim 10^{-4}$ leads to a degassing ${ }^{36} \mathrm{Ar}$ flux of $\sim 5.0 \times 10^{4} \mathrm{~mol} / \mathrm{y}\left(1.8 \times 10^{6} \mathrm{~g}{ }^{36} \mathrm{Ar} / \mathrm{y}\right)$ in Central 499 America. Using $1.4 \times 10^{16} \mathrm{~g}$ of subducted crust, depths of $\sim 6 \mathrm{~km}$ of oceanic crust and $\sim 500$ 500 m of sediments, and the noble gases abundances in the oceanic crust (Chavrit et al., 2016), 501 we derive a ${ }^{36} \mathrm{Ar}$ subduction flux of $1.1 \times 10^{8} \mathrm{~cm}^{3} \mathrm{STP} / \mathrm{y}$, or $4.5 \times 10^{4} \mathrm{~mol}{ }^{36} \mathrm{Ar} / \mathrm{y}$. Because of 502 the large uncertainties in ${ }^{36} \mathrm{Ar}$ concentrations in rocks (Chavrit et al., 2016), this subduction 503 flux estimate is probably associated with a $\sim 50 \%$ uncertainty, and is presented here for 504 illustration only. We note however that subduction and outgassing ${ }^{36} \mathrm{Ar}$ flux compare 
505 favorably. Like nitrogen, our flux analysis seems to allow quantitative release of slab506 derived ${ }^{36} \mathrm{Ar}$ to the mantle wedge, which would not require substantial ${ }^{36} \mathrm{Ar}$ recycling into 507 the deep mantle in this subduction zone. The same conclusion holds for neon. Using a $508{ }^{3} \mathrm{He} /{ }^{22} \mathrm{Ne}$ of $\sim 2 \times 10^{-2}$ (Fig. 6), we obtain a ${ }^{22} \mathrm{Ne}$ degassing flux of $\sim 2.5 \times 10^{2} \mathrm{~mol} / \mathrm{y}\left(5.5 \times 10^{3}\right.$ $509 \mathrm{~g}{ }^{22} \mathrm{Ne} / \mathrm{y}$ ). The ${ }^{22 \mathrm{Ne}} /{ }^{36} \mathrm{Ar}$ of subducting components is largely variable, around a mode of $510 \sim 10^{-2}$ (Chavrit et al., 2016). This yields a ${ }^{22} \mathrm{Ne}$ subduction flux of $1.1 \times 10^{6} \mathrm{~cm}^{3} \mathrm{STP} / \mathrm{y}$, or 4.5

$511 \times 10^{2} \mathrm{~mol}{ }^{22} \mathrm{Ne} / \mathrm{y}$. Again, although large uncertainties must be taken into consideration, the

512 neon subduction and degassing fluxes appear equivalent, arguing in favor of quantitative

$513 \quad{ }^{22} \mathrm{Ne}$ recycling in the central American subduction zone back to the surface.

514 The simplest interpretation of the fluxes derived here is that the Central American 515 subduction zone acts as a subduction barrier for $\mathrm{N}, \mathrm{Ar}$, and $\mathrm{Ne}$ : volcanic fluxes for $\mathrm{N}_{2}, \mathrm{Ar}$, 516 and $\mathrm{Ne}$, determined with the ${ }^{15} \mathrm{~N}^{15} \mathrm{~N}$ approach, no longer require subduction of these 517 elements past the sub-arc melting region in the central American subduction zone.

\section{Conclusion}

521 Gas discharges in Central America are volatile mixtures involving contributions from 522 at least three endmembers: air ( \pm fractionated air), crust, and mantle-derived components.

523 Using $\Delta_{30}$ as a tracer of nitrogen from air in fumaroles and springs, we show that $\mathrm{O}_{2} / \mathrm{N}_{2}$ 524 ratios are unreliable tracers of air in these systems. We also show that $\delta^{15} \mathrm{~N}$ and $\mathrm{N}_{2} / \mathrm{Ar}$ 525 ratios experienced fractionation during water degassing at depth, rendering these 526 unreliable as signatures of air where liquid water is thermodynamically stable. This is 527 problematic since the degassing fractionation may lead to $\delta^{15} \mathrm{~N}$ values that insidiously 
528 mimic MORB gases. This does not seem to affect magmatic components, but more work is

529 needed on Poás - where interaction with the hydrothermal system may be significant,

530 before a firm conclusion can be reached. A preliminary conclusion is that without $\Delta_{30}$ data,

531 the $\delta^{15} \mathrm{~N}-\mathrm{N}_{2}-\mathrm{Ar}$ systematics may be deceptive, and can lead to confusion with regard to the

532 origin of $\mathrm{N}_{2}$ in mixed gases.

533 We derive estimates of $\mathrm{N}_{2} / \mathrm{He}, \mathrm{He} / \mathrm{Ar}$ and $\mathrm{He} / \mathrm{Ne}$ ratios that reliably exclude

534 atmospheric components. $\mathrm{N}_{2}$, Ar and Ne enrichments by two or three orders of magnitude

535 compared to a MORB source are observed. They are attributed to mantle wedge sources

536 incorporating slab-derived gases. Using known ${ }^{3} \mathrm{He}$ degassing fluxes, we calculated $\mathrm{N}_{2}, \mathrm{Ne}$

537 and Ar degassing fluxes for the Central American arc that could balance subduction fluxes,

538 within uncertainties, no longer requiring the Central American arc to have heavily

539 imbalanced volatile cycles.

540

541

542

543

\section{Acknowledgement}

544

This study was supported by the Deep Carbon Observatory through Sloan Foundation

545 grant numbers G-2018-11346 to EDY. This work was also supported by grant G-2016-7206 from

546 the Alfred P. Sloan Foundation and the Deep Carbon Observatory to PHB. Karen Lloyd and

547 Donato Giovannelli are thanked for co-organizing the Subduction meets Biology initiative.

548 Further, we acknowledge the National Science Foundation (NSF) award MGG-2015789 to PHB.

549 We thank Yuri Taran and an anonymous reviewer for constructive and helpful comments.

550 Rosemary Hickey-Vargas is thanked for editorial handling. 


\section{References}

553 Barry, P.H., Lawson, M., Meurer, W.P., Warr, O., Mabry, J.C., Byrne, D.J., Ballentine, C.J., 2016. Noble gases solubility models 554 of hydrocarbon charge mechanism in the Sleipner Vest gas field. Geochim. Cosmochim. Acta 194, $291-309$.

555 Bebout, G.E., Agard, P., Kobayashi, K., Moriguti, T., Nakamura, E., 2013. Devolatilization history and trace element mobility 556 in deeply subducted sedimentary rocks: Evidence from Western Alps HP/UHP suites. Chem. Geol. 342, 1-20.

Bekaert, D.V., Turner, S.J., Broadley, M.W., Barnes, J.D., Halldórsson, S.A., Labidi, J., Wade, J., Walowski, K.J., Barry, P.H., 2020. Subduction-Driven Volatile Recycling: A Global Mass Balance. Annu. Rev. Earth Planet. Sci. 49.

559 Busigny, V., Cartigny, P., Laverne, C., Teagle, D., Bonifacie, M., Agrinier, P., 2019. A re-assessment of the nitrogen geochemical behavior in upper oceanic crust from Hole 504B: Implications for subduction budget in Central

Busigny, V., Cartigny, P., Philippot, P., Ader, M., Javoy, M., 2003. Massive recycling of nitrogen and other fluid-mobile

Carr, M.J., Feigenson, M.D., Patino, L.C., Walker, J.A., 2003. Volcanism and geochemistry in Central America: Progress and

Chavrit, D., Burgess, R., Sumino, H., Teagle, D.A.H., Droop, G., Shimizu, A., Ballentine, C.J., 2016. The contribution of hydrothermally altered ocean crust to the mantle halogen and noble gas cycles. Geochim. Cosmochim. Acta 183, $106-124$

De Leeuw, G.A.M., Hilton, D.R., Fischer, T.P., Walker, J.A., 2007. The He-CO2 isotope and relative abundance characteristics

574 Elkins, L.J., Fischer, T.P., Hilton, D.R., Sharp, Z.D., McKnight, S., Walker, J., 2006. Tracing nitrogen in volcanic and

575 geothermal volatiles from the Nicaraguan volcanic front. Geochim. Cosmochim. Acta 70, 5215-5235.

576 Fischer, T.P., Hilton, D.R., Zimmer, M.M., Shaw, A.M., Sharp, Z.D., Walker, J.A., 2002. Subduction and recycling of nitrogen along the Central American margin. Science (80-. ). 297, 1154-1157.

578 Fischer, T.P., Ramírez, C., Mora-Amador, R.A., Hilton, D.R., Barnes, J.D., Sharp, Z.D., Le Brun, M., de Moor, J.M., Barry, P.H., 579 Füri, E., Shaw, A.M., 2015. Temporal variations in fumarole gas chemistry at Poás volcano, Costa Rica. J. Volcanol. 580 Geotherm. Res. 294, 56-70. https://doi.org/10.1016/j.jvolgeores.2015.02.002 
Fischer, T.P., Takahata, N., Sano, Y., Sumino, H., Hilton, D.R., 2005. Nitrogen isotopes of the mantle: Insights from mineral separates. Geophys. Res. Lett. 32.

Gazel, E., Carr, M.J., Hoernle, K., Feigenson, M.D., Szymanski, D., Hauff, F., Van Den Bogaard, P., 2009. Galapagos-OIB signature in southern Central America: Mantle refertilization by arc-hot spot interaction. Geochemistry, Geophys. Geosystems 10 .

Hilton, D.R., Fischer, T.P., Marty, B., 2002. Noble gases and volatile recycling at subduction zones. Rev. Mineral. geochemistry 47, 319-370.

Hilton, D.R., Ramirez, C.J., Mora-Amador, R., Fischer, T.P., Füri, E., Barry, P.H., Shaw, A.M., 2010. Monitoring of temporal and spatial variations in fumarole helium and carbon dioxide characteristics at Poás and Turrialba volcanoes, Costa Rica (2001-2009). Geochem. J. 44, 431-440.

Hoernle, K., Abt, D.L., Fischer, K.M., Nichols, H., Hauff, F., Abers, G.A., Van Den Bogaard, P., Heydolph, K., Alvarado, G., Protti, M., 2008. Arc-parallel flow in the mantle wedge beneath Costa Rica and Nicaragua. Nature 451, 1094-1097.

Holland, G., Ballentine, C.J., 2006. Seawater subduction controls the heavy noble gas composition of the mantle. Nature 441, 186-191. https://doi.org/10.1038/nature04761

Inguaggiato, S., Taran, Y., Grassa, F., Capasso, G., Favara, R., Varley, N., Faber, E., 2004. Nitrogen isotopes in thermal fluids of a forearc region (Jalisco Block, Mexico): Evidence for heavy nitrogen from continental crust. Geochemistry, Geophys. Geosystems 5.

Jackson, C.R.M., Cottrell, E., Andrews, B., 2021. Warm and oxidizing slabs limit ingassing efficiency of nitrogen to the mantle. Earth Planet. Sci. Lett. 553, 116615.

Javoy, M., Pineau, F., 1991. The volatiles record of a "popping" rock from the Mid-Atlantic Ridge at $14^{\circ} \mathrm{N}$ : chemical and isotopic composition of gas trapped in the vesicles. Earth Planet. Sci. Lett. 107, 598-611.

Keller, B., Schoene, B., 2018. Plate tectonics and continental basaltic geochemistry throughout Earth history. Earth Planet. Sci. Lett. 481, 290-304.

Kennedy, B.M., Hiyagon, H., Reynolds, J.H., 1991. Noble gases from Honduras geothermal sites. J. Volcanol. Geotherm. Res.

606 Labidi, J., Barry, P.H., Bekaert, D. V, Broadley, M.W., Marty, B., Giunta, T., Warr, O., Lollar, B.S., Fischer, T.P., Avice, G., 2020. Hydrothermal 15 N 15 N abundances constrain the origins of mantle nitrogen. Nature 580, 367-371. 
Implications for hydrothermal systems. Geochem. J. 49, 571-573.

613 Lee, J.-Y., Marti, K., Severinghaus, J.P., Kawamura, K., Yoo, H.-S., Lee, J.B., Kim, J.S., 2006. A redetermination of the isotopic 614 abundances of atmospheric Ar. Geochim. Cosmochim. Acta 70, 4507-4512.

615 Li, L., Bebout, G.E., 2005. Carbon and nitrogen geochemistry of sediments in the Central American convergent margin: 616 Insights regarding subduction input fluxes, diagenesis, and paleoproductivity. J. Geophys. Res. Solid Earth 110.

617 Libourel, G., Marty, B., Humbert, F., 2003. Nitrogen solubility in basaltic melt. Part I. Effect of oxygen fugacity. Geochim. 618 Cosmochim. Acta 67, 4123-4135. https://doi.org/10.1016/s0016-7037(03)00259-x

619 Martin, H., Moyen, J.-F., 2002. Secular changes in tonalite-trondhjemite-granodiorite composition as markers of the 620 progressive cooling of Earth. Geology 30, 319-322.

621 Marty, B., Humbert, F., 1997. Nitrogen and argon isotopes in oceanic basalts. Earth Planet. Sci. Lett. 152, $101-112$.

622 Mikhail, S., Sverjensky, D.A., 2014. Nitrogen speciation in upper mantle fluids and the origin of Earth's nitrogen-rich 623 atmosphere. Nat. Geosci. 7, 816-819. https://doi.org/10.1038/ngeo2271

624 http://www.nature.com/ngeo/journal/v7/n11/abs/ngeo2271.html\#supplementary-information

625 Moreira, M., Kunz, J., Allegre, C., 1998. Rare gas systematics in popping rock: isotopic and elemental compositions in the $626 \quad$ upper mantle. Science (80-. ). 279, 1178-1181.

627 Mukhopadhyay, S., 2012. Early differentiation and volatile accretion recorded in deep-mantle neon and xenon. Nature $628 \quad 486,101-104$. https://doi.org/10.1038/nature11141

629 Patino, L.C., Carr, M.J., Feigenson, M.D., 2000. Local and regional variations in Central American arc lavas controlled by 630 variations in subducted sediment input. Contrib. to Mineral. Petrol. 138, 265-283.

631 Peacock, S.M., van Keken, P.E., Holloway, S.D., Hacker, B.R., Abers, G.A., Fergason, R.L., 2005. Thermal structure of the Costa 632 Rica-Nicaragua subduction zone. Phys. Earth Planet. Inter. 149, 187-200.

633 Plank, T., Kelley, K.A., Zimmer, M.M., Hauri, E.H., Wallace, P.J., 2013. Why do mafic arc magmas contain 4 wt\% water on 634 average? Earth Planet. Sci. Lett. 364, 168-179.

635 Ranero, C.R., von Huene, R., 2000. Subduction erosion along the Middle America convergent margin. Nature 404, 748-752. 636 Raquin, A., Moreira, M.A., Guillon, F., 2008. He, Ne and Ar systematics in single vesicles: mantle isotopic ratios and origin of 637 the air component in basaltic glasses. Earth Planet. Sci. Lett. 274, 142-150.

638 Schwarzenbach, E.M., Gill, B.C., Gazel, E., Madrigal, P., 2016. Sulfur and carbon geochemistry of the Santa Elena peridotites: 639 Comparing oceanic and continental processes during peridotite alteration. Lithos 252-253, 92-108.

640 https://doi.org/http://dx.doi.org/10.1016/j.lithos.2016.02.017

641 Snyder, G., Poreda, R., Fehn, U., Hunt, A., 2003. Sources of nitrogen and methane in Central American geothermal settings: 642 Noble gas and 129I evidence for crustal and magmatic volatile components. Geochemistry, Geophys. Geosystems 4, 
1-28.

644 Staudacher, T., Allègre, C.J., 1988. Recycling of oceanic crust and sediments: the noble gas subduction barrier. Earth $645 \quad$ Planet. Sci. Lett. 89, 173-183.

646 Taran, Y.A., 2009. Geochemistry of volcanic and hydrothermal fluids and volatile budget of the Kamchatka-Kuril 647 subduction zone. Geochim. Cosmochim. Acta 73, 1067-1094.

648 Vaselli, O., Tassi, F., Minissale, A., Montegrossi, G., Duarte, E., Fernandez, E., Bergamaschi, F., 2003. Fumarole migration and 649 fluid geochemistry at Poás volcano (Costa Rica) from 1998 to 2001. Geol. Soc. London, Spec. Publ. 213, $247-262$.

650 Warr, O., Rochelle, C.A., Masters, A., Ballentine, C.J., 2015. Determining noble gas partitioning within a CO2-H20 system at 651 elevated temperatures and pressures. Geochim. Cosmochim. Acta 159, 112-125.

652 Yeung, L.Y., Li, S., Kohl, I.E., Haslun, J.A., Ostrom, N.E., Hu, H., Fischer, T.P., Schauble, E.A., Young, E.D., 2017. Extreme 653 enrichment in atmospheric 15N15N. Sci. Adv. 3, eaao6741.

654 Young, E.D., Rumble III, D., Freedman, P., Mills, M., 2016. A large-radius high-mass-resolution multiple-collector isotope 655 ratio mass spectrometer for analysis of rare isotopologues of 02, N2, CH4 and other gases. Int. J. Mass Spectrom. $656401,1-10$

657 Zelenski, M., Taran, Y., 2011. Geochemistry of volcanic and hydrothermal gases of Mutnovsky volcano, Kamchatka:

658 evidence for mantle, slab and atmosphere contributions to fluids of a typical arc volcano. Bull. Volcanol. 73, 373659394

660 Zimmer, M.M., Fischer, T.P., Hilton, D.R., Alvarado, G.E., Sharp, Z.D., Walker, J.A., 2004. Nitrogen systematics and gas fluxes 661 of subduction zones: insights from Costa Rica arc volatiles. Geochemistry, Geophys. Geosystems 5.

\section{Captions}




\begin{tabular}{|c|c|c|c|c|c|c|c|c|c|}
\hline & & PO 06-1-3 & PO 03-2 & Pnar 06-1 & PO 06-1-1 & PO 06-1-2 & ES02 10 & Nic-3 & $\mathrm{Nic}-2$ \\
\hline & & Poas & Poas & Poas & Poas & Poas & Santa Ana & MomotomboN & lomotombg \\
\hline dates of collection & & $11 / 5 / 06$ & $3 / 31 / 03$ & $2 / 24 / 06$ & $2 / 24 / 06$ & $2 / 24 / 06$ & & $1 / 5 / 02$ & $1 / 5 / 02$ \\
\hline latitude & & 10.12 & 10.12 & 10.12 & 10.12 & 10.12 & 13.5111 & 12.2519 & 12.2519 \\
\hline longitude & & -84.1359 & -84.1359 & -84.1359 & -84.1359 & -84.1359 & -89.3748 & -86.3224 & -86.3224 \\
\hline temperature ( $\left.\mathrm{C}^{\circ}\right)$ & & 113 & 98 & 153 & 113 & 113 & 400 & 747 & 747 \\
\hline quantity of processed $\mathrm{N}_{2}$ & $10^{-6} \mathrm{~mol}$ & 2.1 & 2.2 & 8.8 & 8.0 & 5.8 & 22.4 & & \\
\hline $\mathrm{N}_{2}$ vol fraction (ucla) & $\times 10^{-2}$ & $9.21 \mathrm{E}-01$ & $8.47 \mathrm{E}-01$ & $3.10 \mathrm{E}-01$ & 7.43E-01 & $6.01 \mathrm{E}-01$ & $7.14 \mathrm{E}-01$ & & \\
\hline${ }^{15} \mathrm{~N}$ & vs. air & -3.69 & 0.35 & -1.38 & -1.38 & -1.7 & 0.2 & 5.41 & 3.89 \\
\hline 30 & vs. stochastic & 17 & 3.43 & 10.92 & 10.25 & 11 & 15.5 & 1.5 & 3.9 \\
\hline $1 \mathrm{se}{ }^{15} \mathrm{~N}$ & & 0.032 & 0.018 & 0.02 & 0.021 & 0.022 & 0.008 & 0.1 & 0.1 \\
\hline $1 \mathrm{se} 30$ & & 0.496 & 0.527 & 0.288 & 0.309 & 0.307 & 0.138 & 0.3 & 0.2 \\
\hline $\mathrm{CO}_{2}$ & & 0.992 & 0.990 & 0.975 & 0.993 & 0.990 & 0.983 & 0.859 & 0.861 \\
\hline $\mathrm{He}$ & & $4.56 \mathrm{E}-05$ & $5.00 \mathrm{E}-06$ & $5.59 \mathrm{E}-06$ & 4.97E-06 & $8.53 \mathrm{E}-06$ & $6.54 \mathrm{E}-06$ & 7.61E-06 & $1.66 \mathrm{E}-05$ \\
\hline $\mathrm{H}_{2}$ & & $1.17 \mathrm{E}-04$ & $3.25 \mathrm{E}-04$ & $1.40 \mathrm{E}-02$ & $6.62 \mathrm{E}-05$ & $7.05 E-05$ & $4.64 \mathrm{E}-03$ & $1.24 \mathrm{E}-01$ & $1.20 \mathrm{E}-01$ \\
\hline $\mathrm{Ar}$ & & $2.42 \mathrm{E}-04$ & $1.12 \mathrm{E}-04$ & $1.24 \mathrm{E}-04$ & $3.10 E-04$ & $4.21 \mathrm{E}-04$ & $9.98 \mathrm{E}-05$ & $1.52 \mathrm{E}-04$ & 3.70E-05 \\
\hline $\mathrm{O}_{2}$ & & $4.19 \mathrm{E}-04$ & $1.25 \mathrm{E}-05$ & $1.45 \mathrm{E}-04$ & $5.28 \mathrm{E}-04$ & $7.90 \mathrm{E}-04$ & $4.54 \mathrm{E}-06$ & $1.14 \mathrm{E}-05$ & 8.93E-06 \\
\hline $\mathrm{N}_{2}$ & & $6.70 \mathrm{E}-03$ & $1.00 \mathrm{E}-02$ & $1.06 \mathrm{E}-02$ & $6.56 \mathrm{E}-03$ & $8.94 \mathrm{E}-03$ & $1.20 \mathrm{E}-02$ & $1.62 \mathrm{E}-02$ & $1.88 \mathrm{E}-02$ \\
\hline $\mathrm{CH}_{4}$ & & $6.44 \mathrm{E}-06$ & $1.25 \mathrm{E}-06$ & $1.20 \mathrm{E}-04$ & $7.24 \mathrm{E}-06$ & $9.48 \mathrm{E}-06$ & $1.95 \mathrm{E}-05$ & $8.88 \mathrm{E}-06$ & 7.66E-06 \\
\hline $\mathrm{He} / \mathrm{Ar}$ & & $1.89 \mathrm{E}-01$ & $4.44 \mathrm{E}-02$ & $4.50 \mathrm{E}-02$ & $1.60 \mathrm{E}-02$ & $2.03 \mathrm{E}-02$ & $6.55 \mathrm{E}-02$ & $5.00 \mathrm{E}-02$ & $4.48 \mathrm{E}-01$ \\
\hline $\mathrm{N}_{2} / \mathrm{He}$ & & $1.47 \mathrm{E}+02$ & $2.00 E+03$ & $1.91 E+03$ & $1.32 E+03$ & $1.05 \mathrm{E}+03$ & $1.83 E+03$ & $2.13 E+03$ & $1.13 E+03$ \\
\hline $\mathrm{N}_{2} / \mathrm{Ar}$ & & $2.77 E+01$ & $8.89 E+01$ & $8.58 E+01$ & $2.11 E+01$ & $2.12 \mathrm{E}+01$ & $1.20 E+02$ & $1.07 E+02$ & $5.07 E+02$ \\
\hline $\mathrm{O}_{2} / \mathrm{N}_{2}$ & & $6.25 \mathrm{E}-02$ & $1.25 \mathrm{E}-03$ & $1.36 \mathrm{E}-02$ & 8.04E-02 & $8.83 E-02$ & $3.80 \mathrm{E}-04$ & $7.03 E-04$ & 4.76E-04 \\
\hline $\mathrm{N}_{2} / \mathrm{CH}_{4}$ & & $1.04 \mathrm{E}+03$ & $8.00 \mathrm{E}+03$ & $8.87 E+01$ & $9.06 \mathrm{E}+02$ & $9.43 E+02$ & $6.14 \mathrm{E}+02$ & $1.83 E+03$ & $2.45 \mathrm{E}+03$ \\
\hline${ }^{40} \mathrm{Ar} /{ }^{36} \mathrm{Ar}$ & & & & & 297 & 293 & & 305 & \\
\hline${ }^{3} \mathrm{He} /{ }^{4} \mathrm{He}$ & $\left(R_{A}\right)$ & 6.44 & 7.15 & 6.96 & 7.15 & 7.15 & 7.56 & 6.99 & 6.99 \\
\hline $\mathrm{N}_{2} /{ }^{3} \mathrm{He}$ & & $1.63 \mathrm{E}+07$ & $2.00 E+08$ & $1.96 \mathrm{E}+08$ & $1.32 E+08$ & $1.05 E+08$ & $1.73 E+08$ & $2.18 \mathrm{E}+08$ & $1.16 \mathrm{E}+08$ \\
\hline $\mathrm{N}_{2} / /^{36} \mathrm{Ar}$ & & $8.49 \mathrm{E}+03$ & $2.72 \mathrm{E}+04$ & $2.62 E+04$ & $6.47 E+03$ & $6.49 \mathrm{E}+03$ & & $3.26 E+04$ & $1.78 \mathrm{E}+05$ \\
\hline${ }^{4} \mathrm{He} /{ }^{20} \mathrm{Ne}$ & & $8.93 E+00$ & $1.90 \mathrm{E}+02$ & $3.61 E+02$ & $1.56 \mathrm{E}+02$ & $1.56 \mathrm{E}+02$ & $6.66 \mathrm{E}+01$ & $2.75 E+02$ & $2.75 E+02$ \\
\hline${ }^{3} \mathrm{He} /{ }^{22} \mathrm{Ne}$ & & $8.04 \mathrm{E}-04$ & $1.90 \mathrm{E}-02$ & $3.52 \mathrm{E}-02$ & $1.56 \mathrm{E}-02$ & $1.56 \mathrm{E}-02$ & $7.05 \mathrm{E}-03$ & $2.69 \mathrm{E}-02$ & 2.69E-02 \\
\hline$x$ value & & 28 & 596 & 1133 & 488 & 488 & 209 & 864 & 864 \\
\hline${ }^{3} \mathrm{He} /{ }^{36} \mathrm{Ar}$ & & $5.20 \mathrm{E}-04$ & $1.36 \mathrm{E}-04$ & $1.34 \mathrm{E}-04$ & $4.90 \mathrm{E}-05$ & $6.20 \mathrm{E}-05$ & & $1.50 \mathrm{E}-04$ & \\
\hline${ }^{4} \mathrm{He} /{ }^{40} \mathrm{Ar}$ & & $1.89 \mathrm{E}-01$ & 4.46E-02 & $4.51 \mathrm{E}-02$ & $1.61 \mathrm{E}-02$ & $2.03 \mathrm{E}-02$ & & $5.02 \mathrm{E}-02$ & \\
\hline
\end{tabular}

666 Table 1. Nitrogen and light noble gases isotope and concentrations for central 


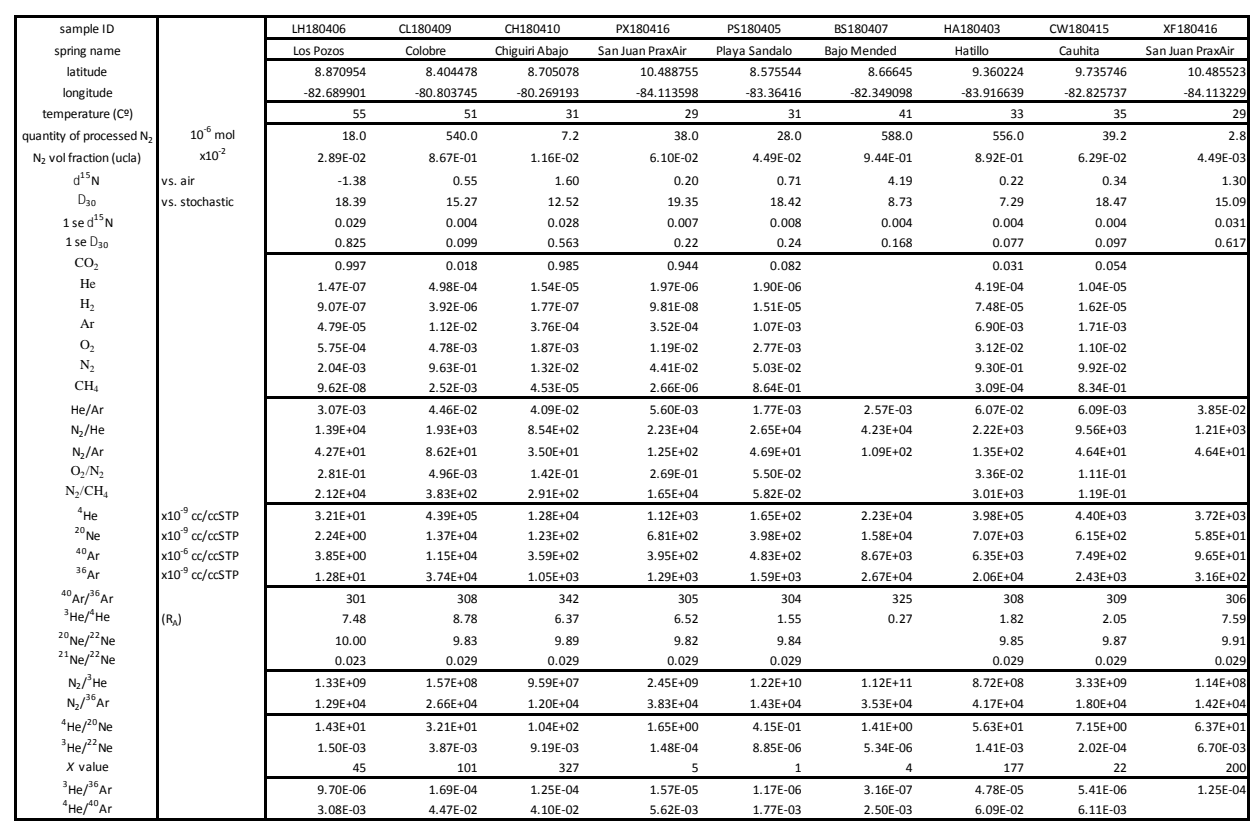
American springs 


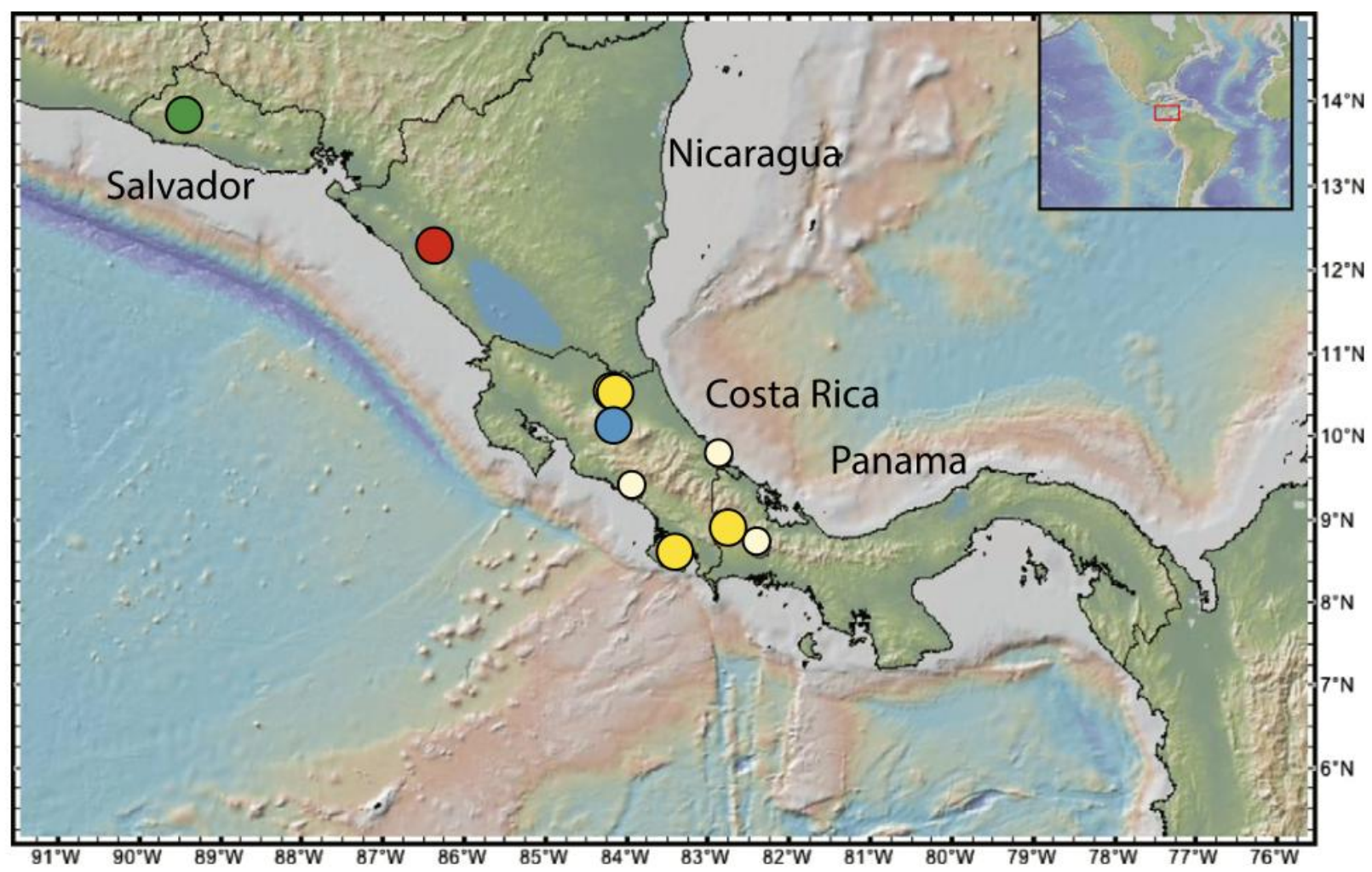

Fig. 1: location of all the samples studied here.

674 Green, red and blue symbols are fumarole locations from Santa Ana, Momotombo and Poás

675 (Data in table 1). Yellow symbols are springs (Data in table 2). 


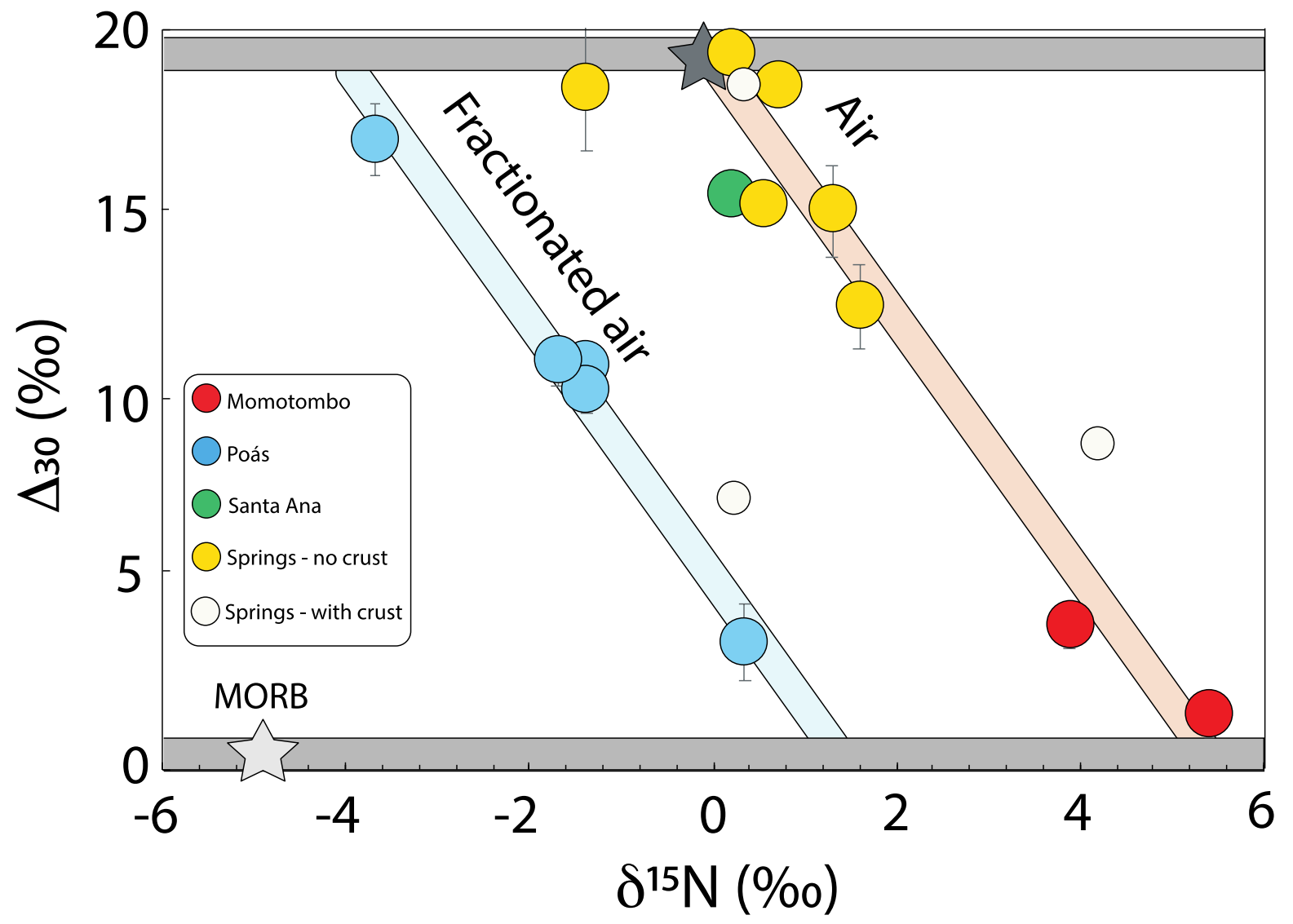

678 Fig. 2 the nitrogen isotopic composition of volcanic discharges in central America.

679 Variable $\Delta_{30}$ values establish that our samples incorporate variable amounts of atmospheric 680 nitrogen. Fumaroles from the Poás and Momotombo have the lowest $\Delta_{30}$ values indicating 681 they have the lowest air-derived $\mathrm{N}_{2}$ contributions while the hot springs from Costa Rica 682 have the highest air contributions. Variable $\delta^{15} \mathrm{~N}$ values are observed, between $-3.7 \pm 0.3 \%$ o 683 and $+4.2 \pm 0.3 \%$. At an air $\Delta_{30}$ values, variable $\delta^{15} \mathrm{~N}$ must be caused by a mass-dependent 684 isotope fractionation, presumably associated with hydrothermal degassing. The high685 temperature components have positive $\delta^{15} \mathrm{~N}$ values. 


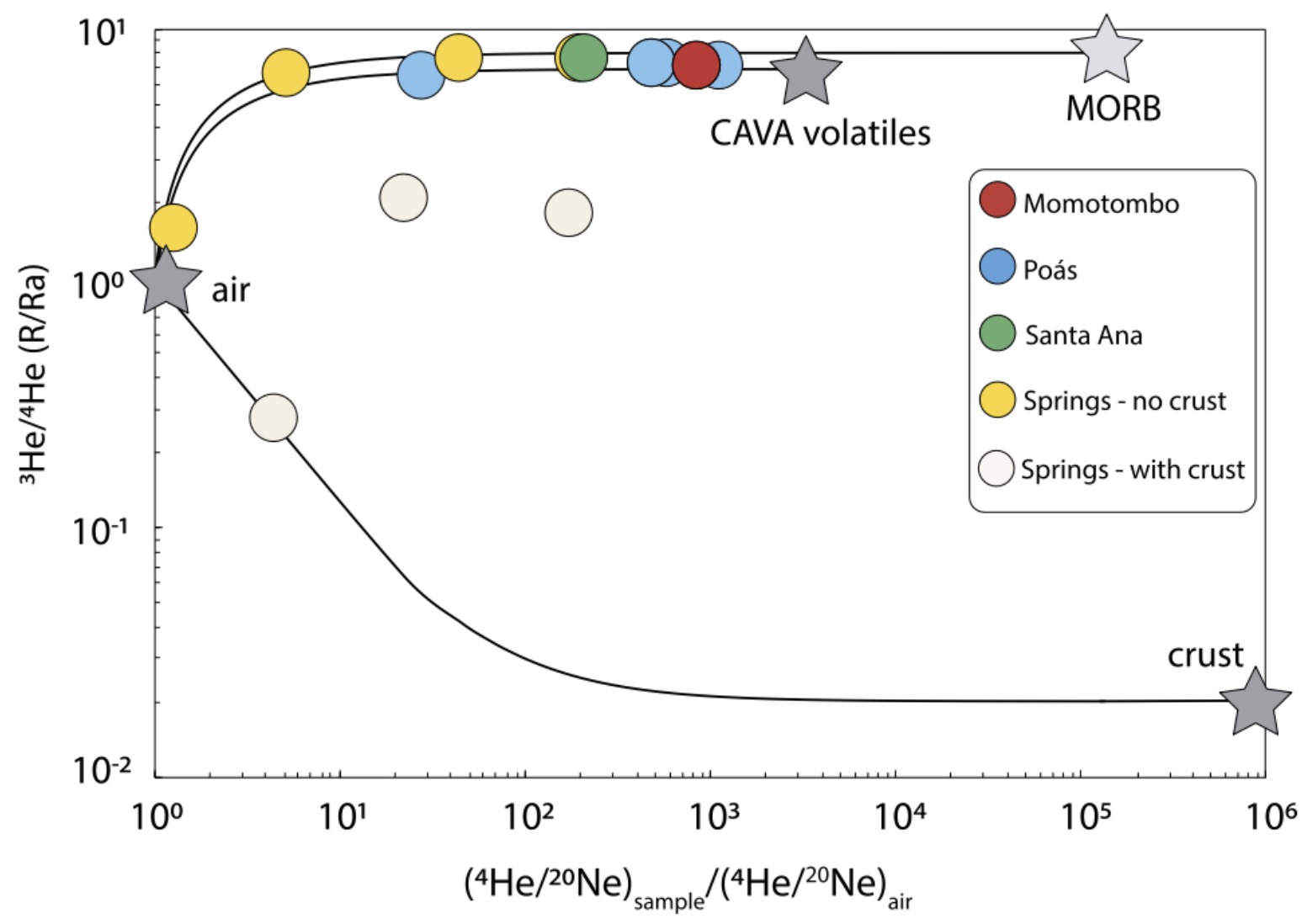

686

687 Fig. 3: Measured ${ }^{3} \mathrm{He} /{ }^{4} \mathrm{He}$ ratios versus ${ }^{4} \mathrm{He} /{ }^{20} \mathrm{Ne}$ ratios of the samples, normalized to air by 688 convention (De Leeuw et al, 2007). Most samples indicate simple two-component air-magma 689 mixing. Three Costa Rica hot springs (HS) however show additions of crustal ${ }^{4} \mathrm{He}$. 

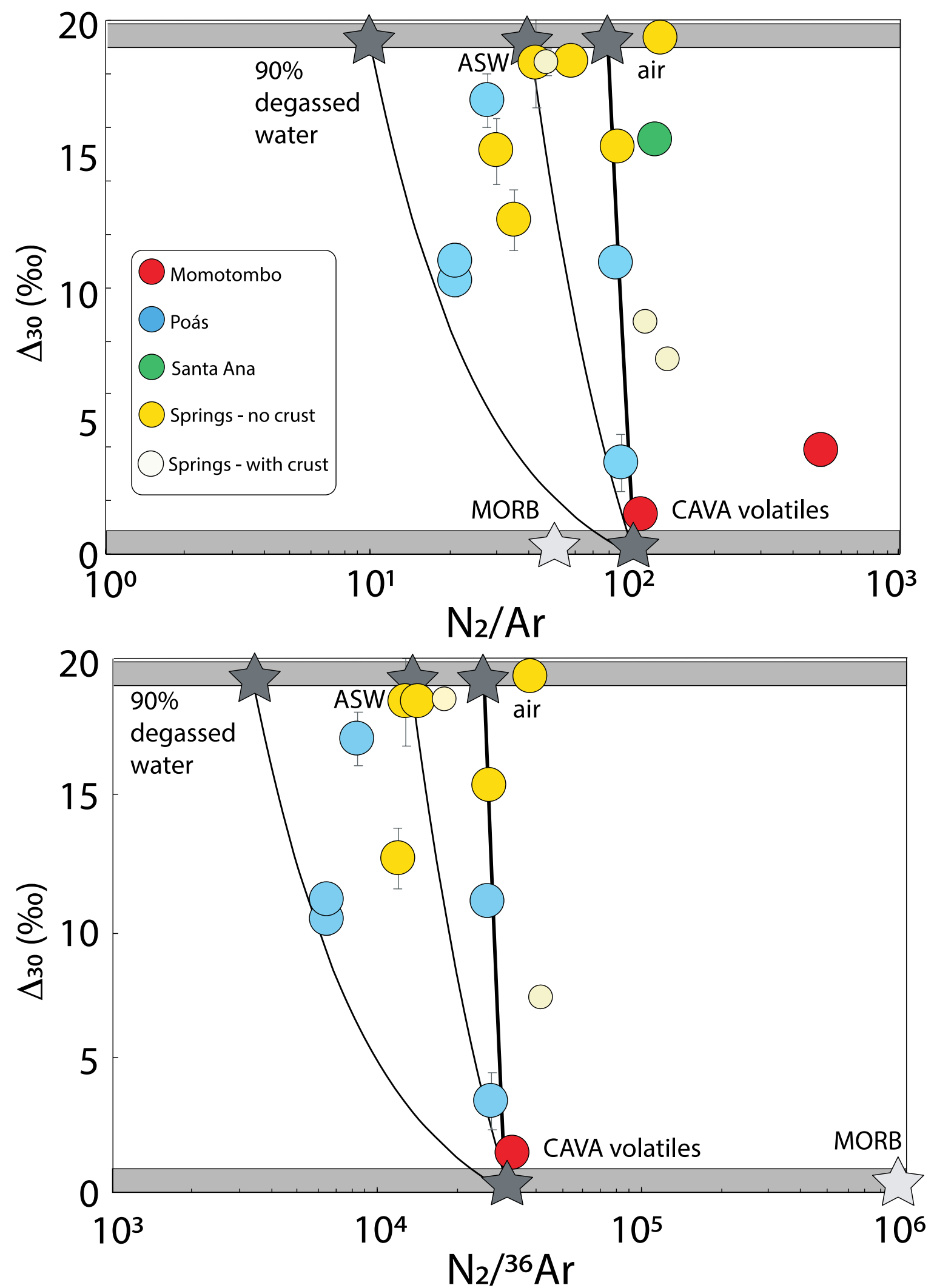
Fig. 4: Measured $N_{2} / A r$ and $N_{2} /{ }^{36} A r$ ratios versus $\Delta_{30}$ values. Mixing lines are shown for mixtures between the high-temperature component observed at both Momotombo and Poás, and variably fractionated atmospheric components, including air, air-saturated water (ASW), and degassed water. The high-temperature endmembers with $\Delta_{30}=0 \%$ defined by the data from Momotombo and Poás have similar $\mathrm{N}_{2} / \mathrm{Ar}$ and $\mathrm{N}_{2} /{ }^{36} \mathrm{Ar}$ ratios of $\sim 100$ and $\sim 10^{4}$, respectively. Here, we adopt values of $\sim 100$ and $3 \times 10^{4}$ for $\mathrm{N}_{2} / \mathrm{Ar}$ and $\mathrm{N}_{2} /{ }^{36} \mathrm{Ar}$ ratios for the high-T endmember at Momotombo. Nitrogen and argon have indistinguishable solubilities in silicate melts and thus are not fractionated by magmatic degassing at $\sim 1200$ ${ }^{\circ} \mathrm{C}$ (Libourel et al., 2003). Thus, the low $\mathrm{N}_{2} /{ }^{36} \mathrm{Ar}$ at Momotombo is not resulting from fractionations during magmatic degassing. Instead, it may be a feature of the Momotombo mantle source. At Poás, fumarole samples are consistent with the same $\mathrm{N}_{2} / \mathrm{Ar}$ ratio for the high-temperature component as at Momotombo. If hydrothermal degassing affected the high-T volatiles at Poás, the pristine $\mathrm{N}_{2} / \mathrm{Ar}$ and $\mathrm{N}_{2} /{ }^{36} \mathrm{Ar}$ for high-T gases at Poás could be higher than the observed values. Note that combining a ${ }^{3} \mathrm{He} /{ }^{36} \mathrm{Ar}$ ratio of $\sim 10^{-4}$ (see Fig. 6B) to the observed $\mathrm{N}_{2} /{ }^{3} \mathrm{He}$ of $\sim 10^{8}$ (Fig. 4) returns to a $\mathrm{N}_{2} /{ }^{36} \mathrm{Ar}$ of $\sim 10^{4}$, consistent with the conclusion of a low $\mathrm{N}_{2} / \mathrm{Ar}$ in our sampling of high-temperature endmembers (see 707 section 5.4). 

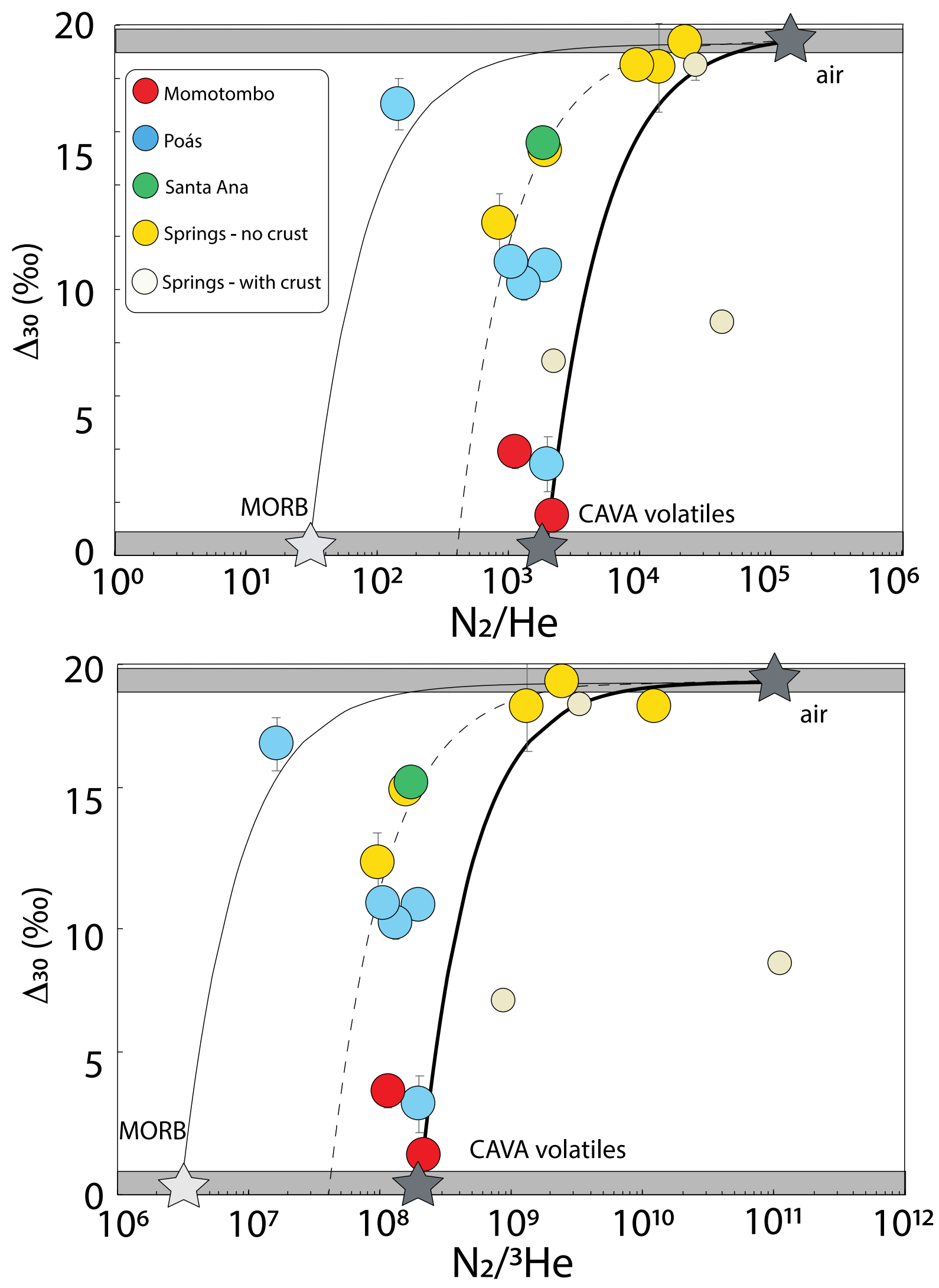
710 Fig. 5: Measured $\mathbf{N}_{2} / \mathrm{He}$ and $\mathbf{N}_{2} /{ }^{3} \mathrm{He}$ ratios versus $\Delta_{30}$ values. Mixing lines are shown for 711 mixtures between air and three high-temperature components: MORBs, and two variably $\mathrm{N}_{2^{-}}$ 712 enriched endmembers required to fit the data. Springs with additions of crustal ${ }^{4} \mathrm{He}$ are shown 713 in the smallest symbols. They are not used for fluxes calculations - see discussion in the 714 supplementary discussion. 

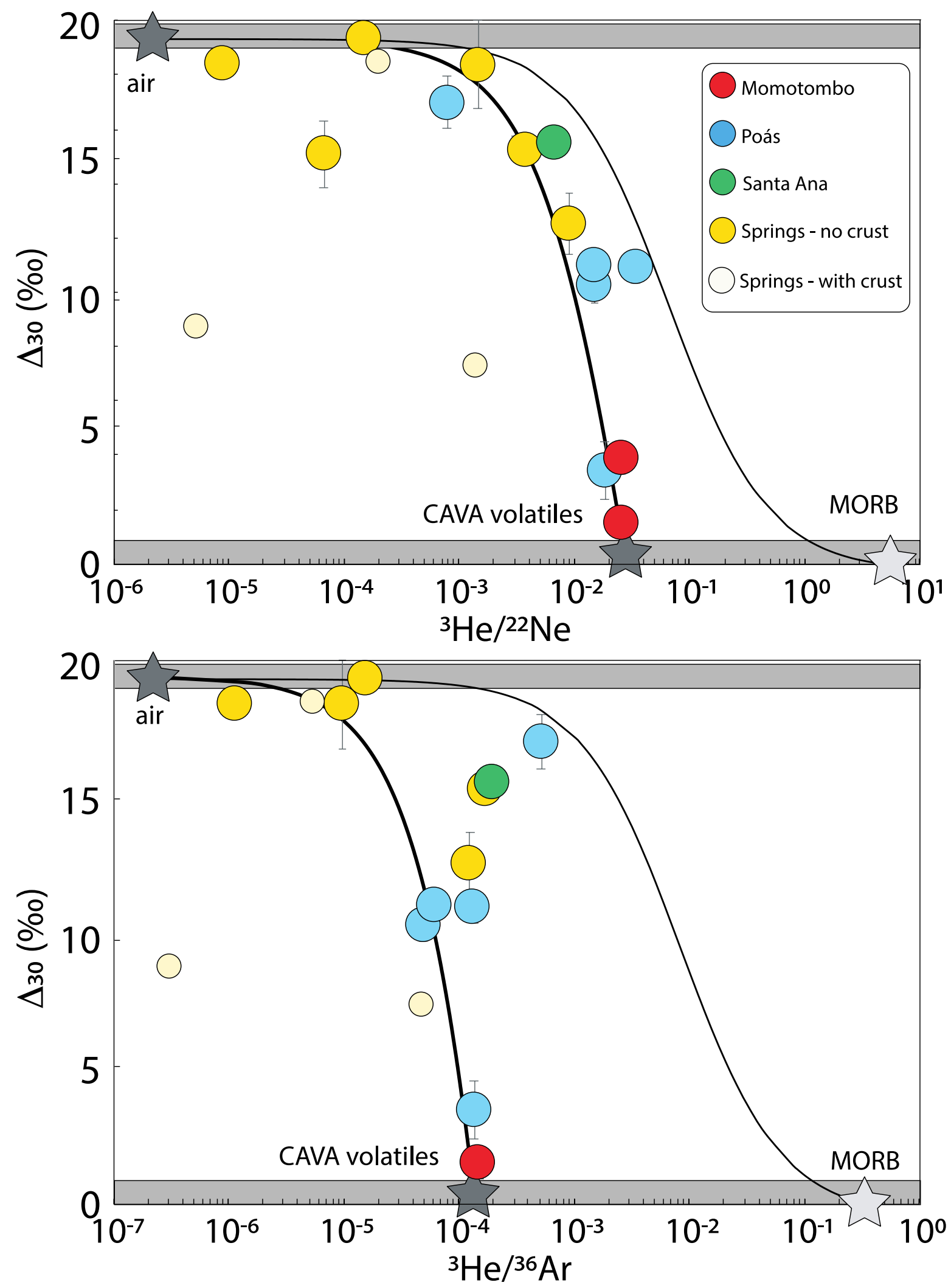
Fig. 6: Measured ${ }^{3} \mathrm{He} /{ }^{22} \mathrm{Ne}$ and ${ }^{3} \mathrm{He} /{ }^{36} \mathrm{Ar}$ ratios versus $\Delta_{30}$ values. Springs with additions of crustal ${ }^{4} \mathrm{He}$ are shown in the smallest symbols. They are not used for fluxes calculations - see discussion in the supplementary discussion. Mixing lines are the same as in figure 3 and 4 . They are shown for mixtures between air and high-temperature components: MORB, and a $\mathrm{N}_{2}{ }^{36} \mathrm{Ar}$ ${ }^{22} \mathrm{Ne}$ enriched endmember that fits the data. The mixing relationships are curved because of the logarithm scale, but also because of how distinct the $\mathrm{N}_{2} / \mathrm{Ne}$ of the mixing endmembers may be. Air has a $\mathrm{N}_{2} /{ }^{20} \mathrm{Ne}$ ratio of air is $4.5 \times 10^{4}$. For MORB, we calculate a the $\mathrm{N}_{2} /{ }^{20} \mathrm{Ne}$ of $1.3 \times 10^{6}$. This is based on a $\mathrm{N}_{2} /{ }^{3} \mathrm{He}$ of $3 \times 10^{6}$ for the MORB mantle (Javoy and Pineau, 1991). We combine this $\mathrm{N}_{2} /{ }^{3} \mathrm{He}$ estimate with ${ }^{3} \mathrm{He} /{ }^{4} \mathrm{He}$ and ${ }^{4} \mathrm{He} /{ }^{20} \mathrm{Ne}$ values for the MORB mantle from Moreira et al (1998). Using the ${ }^{3} \mathrm{He} /{ }^{22} \mathrm{Ne}$ ratio of the MORB mantle (Moreira et al., 1998), we derive a $\mathrm{N}_{2} /{ }^{22} \mathrm{Ne}$ of $1.7 \times 10^{7}$. Conversely, we here derive $\mathrm{N}_{2} /{ }^{3} \mathrm{He},{ }^{3} \mathrm{He} /{ }^{22} \mathrm{Ne}$ ratios of the central American high-temperature volatiles. Combining those with ${ }^{3} \mathrm{He} /{ }^{4} \mathrm{He}$ of $\sim 7$ from Fig. 3, we derive $\mathrm{N}_{2} /{ }^{20} \mathrm{Ne}$ and $\mathrm{N}_{2} /{ }^{22} \mathrm{Ne}$ ratios of $3.4 \times 10^{5}$ and $3.3 \times 10^{6}$, respectively. On panel $b$, the curvatures are function the $\mathrm{N}_{2} / \mathrm{Ar}$ of the mixing endmembers, which are estimated on Fig. 4.

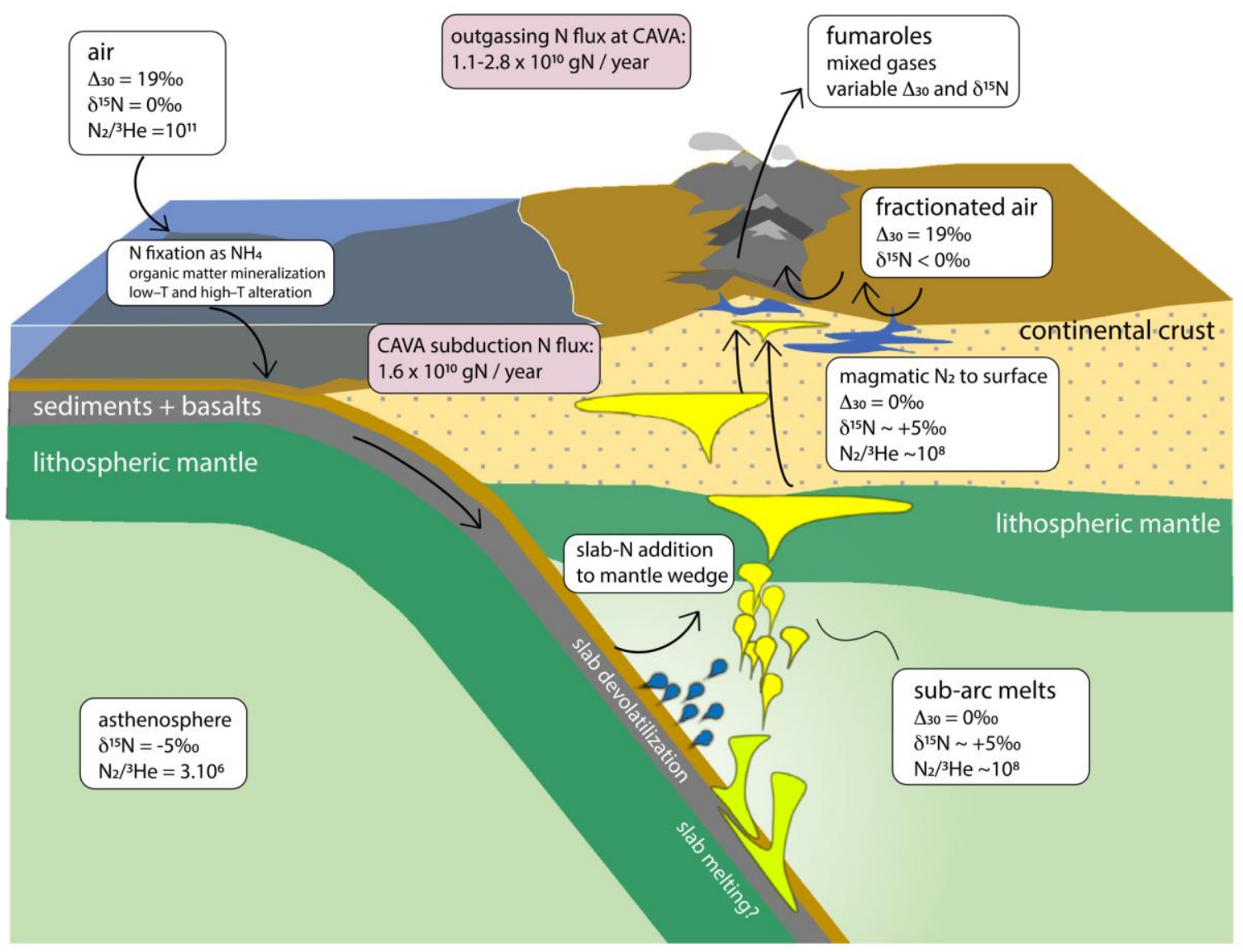

Fig. 7 Cartoon representing various processes and reservoirs constrained in this study. Scales are grossly exaggerated, especially for melt conduits and magma chambers. A slab with sediments, basalts, and oceanic lithospheric mantle is shown to enter subduction. The slab composition is not constrained here but is likely enriched in all volatiles relative to ${ }^{3} \mathrm{He}$ (Busigny et al., 2019, Chavrit et al., 2016). In the slab, nitrogen is fixed as $\mathrm{NH}_{4}{ }^{+}$(Busigny et al., 2019 and 
737 references therein) so no $\Delta_{30}$ values are defined; $\Delta_{30}$ is only relevant for $\mathrm{N}_{2}$ molecules. Both slab 738 devolatilization and slab melting are shown for illustration. Any slab melting would be relevant 739 underneath Costa Rica (Hoernle et al., 2008) while slab devolatilization and sediment-derived 740 fluids would contribute to sources underneath Nicaragua and El Salvador (Patino et al., 2000).

741 The melting region is characterized as the high-temperature endmembers constrained in this 742 work (Fig. 7). Melts and super-critical fluids are suggested to host dissolved $\mathrm{N}_{2}$ (Libourel et al., 743 2003; Mikhail and Sverjensky, 2014). Upon partial melting of a $\mathrm{NH}_{3}$-bearing mantle source, 744 magmatic $\mathrm{N}_{2}$ would form with a $\Delta_{30}$ of $0 \%$. The high-T $\mathrm{N}_{2}$ is then contributed to hydrothermal 745 systems in the sub-surface by near-quantitative magmatic degassing. Air circulation in the sub746 surface allows air-saturated waters to undergo degassing, and subsequent gas release with 747 fractionated compositions. 